Terr. Atmos. Ocean. Sci., Vol. 18, No. 3, 515-545, August 2007

\title{
A Study of Tropospheric Ozone over China with a 3-D Global CTM Model
}

\author{
Li Liu ${ }^{1,}{ }^{*}$, Jostein K. Sundet ${ }^{1}$, Yu Liu ${ }^{2}$, Terje K. Berntsen ${ }^{3}$, and Ivar S. A. Isaksen ${ }^{1}$
}

(Manuscript received 30 October 2006, in final form 2 March 2007)

\begin{abstract}
A global 3-D CTM model (OsloCTM2) has been used to study the tropospheric ozone distribution and budget over China. An area covering China and most of East Asia is chosen as the study area. Because of the very unevenly distributed emissions and population in China, the budget study has been done by splitting China into three sub-areas, according to the emission distribution and topography of the country. The model results indicate that in Western China (Area1) dynamic processes are dominating, and the contribution from photochemical ozone production is small. Central and South-East China (Area2) has on average $65 \%$ of the photochemical ozone production in China, since more than $80 \%$ of the anthropogenic emissions come from this area. Northeast China (Area3) is influenced both by natural and*9nthropogenic emissions. The seasonal variation of ozone budgets was calculated in order to understand how different processes vary with the seasons. The strongest influences of emissions from the continent over the West Pacific region are found in spring, because of the large eastward transport and increased photochemical activities. Most $\mathrm{NO}_{\mathrm{x}}$ is consumed close to the emission sources; therefore, only $4 \%$ of emitted $\mathrm{NO}_{\mathrm{x}}$ is transported out of China, whereas $70 \%$ of the emitted $\mathrm{CO}$ is exported. It is calculated that the average net chemical ozone production efficiency by $\mathrm{NO}_{\mathrm{x}}$ loss is 7.2 in China.
\end{abstract}

(Key words: Troposphere, Ozone, CTM, Budget, China)

\footnotetext{
${ }^{1}$ Department of Geosciences, University of Oslo, Oslo, Norway

${ }^{2}$ Chinese Academy of Meteorological Sciences, Beijing, China

${ }^{3}$ Center for International Climate and Environmental Research, Oslo, Norway

* Corresponding author address: Dr. Li Liu, Department of Geosciences, University of Oslo, Oslo, Norway; E-mail: lil@geo.uio.no
} doi: 10.3319/TAO.2007.18.3.515(EA) 


\section{INTRODUCTION}

A number of model studies and ground-based measurements show a notable increase of surface ozone in the Northern Hemisphere since pre-industrial times. During the late $19^{\text {th }}$ century surface ozone mixing ratios were approximately $10 \mathrm{ppbv}$ over Europe (Anfossi et al. 1991; Marenco et al. 1994). This mixing ratio has increased around four times to $30-50 \mathrm{ppbv}$ as typical values over industrial areas (Pavelin et al. 1999). These increases are mainly driven by the increases in ozone precursors like $\mathrm{NO}_{\mathrm{x}}\left(\mathrm{NO}+\mathrm{NO}_{2}\right), \mathrm{CO}$, and $\mathrm{NMHC}$ (non-methane hydrocarbons) emitted from anthropogenic fossil fuel combustion and biomass burning. The measurements are scarce in South Africa and Asia, but also indicate enhanced ozone levels in the last few decades (Sandroni et al. 1992; Zhou et al. 1993; Naja and Lal 1996). Future emissions are expected to increase in developing countries, especially in South and Southeast Asia (van Aardenne et al. 1999; Streets et al. 2000; Chinese NEPA 2004).

The largest increase in energy consumption is projected for China (Foell et al. 1995). Factors such as population growth, rising per capita income, rising living standards, and future industrialization will increase the energy consumption in the coming decades (International Energy Outlook 2001). China is presently the largest emitter of $\mathrm{NO}_{\mathrm{x}}$ in Asia already (accounting for $43 \%$ of the total in Asia), and will remain so in the next decades. Emissions of $\mathrm{NO}_{\mathrm{x}}$ are predicted to increase by a factor of 4 from 2000 to 2020, making it the largest emitter in the world (van Aardenne et al. 1999). The enhanced ozone close to the surface damages vegetation, agricultural crops, and human health. According to previous studies in China, the loss of agricultural production of winter wheat, corn and soybean are 4.740, 4.929, and 1.546 million tons each year, respectively, when ozone concentrations reach $50 \mathrm{ppbv}$ during the growing season (Wang and Guan 1995). Ozone levels in China have been observed to reach more than 100 ppbv in some areas (Chameides et al. 1998; Wang et al. 2006), and measurements indicate that current levels of surface ozone in remote areas also have increased (Zhou et al.1995). Thus, ozone damage to vegetation could become a serious problem for China's food production in the near future (Kristin et al. 2000).

Temporal and geographical ozone distribution and variation over China has been of great interest in recent years. Several experiments have been carried out in China and in the Pacific region (Xu et al. 1995; Wang et al. 2006). Measurements and achieved emissions inventories from these projects are widely used. Recent satellite observations have supplied valuable information of gross pictures over this region; and the data have been used for determining trends in tracer gases and evaluation of models (Richter et al. 2005; Ma et al. 2006). Some studies show that dynamic processes are important in Western China whereas photochemistry is a determining factor in Eastern China (Yang et al. 1999; Ma et al. 2002b; Zhao et al. 2006). Because of strong westerly winds in the Northern Hemisphere, long-range transport is important for this region, especially during the spring. Previous studies have indicated that Chinese emissions have important influences over the regions east of China (Berntsen et al. 1999; Jaffe et al. 1999, 2003). The air quality standards in some regions are exceeded due to polluted air masses from China (Hudman et al. 2004; Tanimoto et al. 2005). At the same time, a model study by Wang et al. (2006) also showed that there is import of ozone and other tracer gases from countries into the south and east of China. Various studies show general agreement on the gross features of ozone distribution and variations over China. However, studies utilizing 
different modeling tools and different emission inventories suggest differences in concentrations of ozone and its precursors, ozone production rates, transport and so on (Luo et al. 2000; Mauzerall et al. 2000; Ma et al. 2002c; Ma and van Aardenne 2004; Zhao et al. 2006).

In this work, a global photochemical transport model, OsloCTM2, was used. The model has been evaluated and applied to study the seasonal and geographical variations of ozone in China. Furthermore, the study focused on the budgets of ozone and its precursors in China. We are aware that China's populations as well as the emissions are very unevenly distributed, and the characteristics of ozone production and loss processes could be quite different in various regions. Therefore three sub-areas in China were defined according to emission distribution and geographical features in China.

\section{MODEL DESCRIPTION}

OsloCTM2 is an off-line global 3-D chemical transport model (Sundet 1997). Pre-calculated transport and physical fields from the IFS model at the ECMWF are used to simulate chemical processes in the atmosphere. T21 $\left(5.625^{\circ} \times 5.625^{\circ}\right)$ resolution is used in this work. The vertical resolution is 19 hybrid layers, extending from the surface up to $10 \mathrm{hPa}$.

The model solves the 3-D continuity equation of tracer concentrations. The advection scheme is a Second-Order moments method (Prather 1986). Convection is calculated based on convective conservation of mass fluxes taken from the IFS data. The model has an extensive chemical scheme with 120 thermal and 20 photolysis reactions. Spatial and temporal variation of 51 chemical compounds related to tropospheric $\mathrm{O}_{3}$ chemistry is calculated, of which 41 compounds are transported. The time dependent equations are solved based on the QSSA approach (Hesstvedt et al. 1978; Berntsen and Isaksen 1997, 1999). Photo-dissociation rates are calculated on-line with the fast-J scheme (Wild et al. 2000). A detailed wet deposition scheme was described by Berglen et al. (2004). Dry deposition is parameterised with a scheme from Isaksen and Rodhe (1978). The values of dry deposition velocity are taken from Hough (1991). In the model, a constant ozone flux fixed in the top model layer is $450 \mathrm{Tg} \mathrm{yr}^{-1}$, distributed with latitude, thus the ozone in the lower stratosphere is determined by the model transport. The tropopause has been defined with a preset ozone mixing ratio of $150 \mathrm{ppbv}$, so the input from the stratosphere is simulated with transport. In order to get reasonable $\mathrm{NO}_{\mathrm{x}}$ and $\mathrm{HNO}_{3}$ concentrations in the lower stratosphere, we set $\mathrm{NO}_{y}=\mathrm{NO}_{\mathrm{x}}+\mathrm{HNO}_{3}$ and then calculate the concentration of $\mathrm{NO}_{\mathrm{y}}$ according to the ratio between $\mathrm{NO}_{\mathrm{y}}$ and $\mathrm{O}_{3}$ concentration, $\mathrm{NO}_{\mathrm{y}} / \mathrm{O}_{3}$ is 0.004 (Fahey et al. 1996). We assume that $5 \%$ of $\mathrm{NO}_{\mathrm{y}}$ is $\mathrm{NO}_{\mathrm{x}}$ and $95 \%$ of $\mathrm{NO}_{\mathrm{y}}$ is $\mathrm{HNO}_{3}$.

\subsection{Emissions}

Surface emissions of $\mathrm{CO}, \mathrm{NO}_{\mathrm{x}}$, and $\mathrm{NMHC}$ have both anthropogenic and natural sources. Emission data used in this study are taken from the EDGAR and the MULLER database. The natural sources include emissions from ocean, soil and biomass burning. Isoprene is from the GEIA database and has been scaled down to $220 \mathrm{Tg} \mathrm{yr}^{-1}$ (Brasseur et al. 1998). $\mathrm{NO}_{\mathrm{x}}$ from lighting is $5 \mathrm{Tg} \mathrm{yr}^{-1}$ (Price et al. 1997) and is connected to the convection in the model (Berntsen et al. 1999). Global emission rates and its main categories used in the model simulation are shown in Table 1. 
Table 1. Global surface emission rates and categories applied in the model.

\begin{tabular}{|c|c|c|c|c|c|}
\hline \multicolumn{3}{|l|}{ Sources } & $\begin{array}{c}\mathrm{CO} \\
\operatorname{Tg}(\mathrm{C}) / \mathrm{yr}\end{array}$ & $\begin{array}{c}\mathrm{NO}_{\mathrm{x}} \\
\mathrm{Tg}(\mathrm{N}) / \mathrm{yr}\end{array}$ & $\begin{array}{l}\text { NMHC } \\
\operatorname{Tg}(\mathrm{C}) / \mathrm{yr}\end{array}$ \\
\hline \multirow{6}{*}{ Natural } & \multicolumn{2}{|l|}{ Ocean } & 50 & -- & 4.3 \\
\hline & \multicolumn{2}{|l|}{ Soil } & 190 & 5.5 & 27.7 \\
\hline & \multirow{3}{*}{ Biomass } & Forest & 56 & 1.3 & 5.9 \\
\hline & & Savanna & 76 & 2.9 & 9.6 \\
\hline & & Waste & 88 & 2.2 & 19.6 \\
\hline & Burning & Total & 219 & 6.4 & 35.1 \\
\hline \multirow[t]{3}{*}{ Anthropogenic } & \multicolumn{2}{|l|}{ Bio-fuel } & 78 & 4.1 & 15.6 \\
\hline & \multicolumn{2}{|c|}{ Fossil fuel } & 130 & 24.1 & 42.9 \\
\hline & \multicolumn{2}{|l|}{ Industrial } & 18 & 1.5 & 39.4 \\
\hline \multicolumn{3}{|l|}{ Total } & 675 & 41.6 & 165.9 \\
\hline
\end{tabular}

\section{EMISSION DISTRIBUTIONS IN CHINA}

Table 2 shows surface emissions over China. In this inventory, China represents $16.4 \%$ of $\mathrm{NO}_{\mathrm{x}}\left(6.84 \mathrm{Tg} \mathrm{yr}^{-1}\right), 16.1 \%$ of $\mathrm{CO}\left(109 \mathrm{Tg} \mathrm{yr}^{-1}\right)$, and $13.3 \%$ of NMHC $\left(22.0 \mathrm{Tg} \mathrm{yr}^{-1}\right)$ of world emissions. Figure 1 shows the emission distribution (Figs. 1a, b, c) and population density (Fig. 1d) in China. The population density is very high in East China, where $43 \%$ of the land contains $94 \%$ of the population, and only about $6 \%$ of the population is found in the more than $50 \%$ landmass of China's territory in the west (China's State Statistics Bureau 1997). This uneven population distribution is reflected in the emission distribution: about $80 \%$ of the pollutants are emitted from Central and South-East China.

Following the emission distribution and topography in China, we split China into three sub-areas (See Fig. 3) for more explicit analysis of the chemical and physical processes in these sub-regions. The purpose of this experiment is to understand the ozone production/loss processes in China better by analyzing oxidation capacities over these smaller and more homogeneous areas. Table 2 gives information about the $\mathrm{NO}_{x}, \mathrm{CO}$, and $\mathrm{NMHC}$ emission distribution in the three areas: Area1 covers the western part of China, with complex topography, including the Tibetan Plateau and the Takelamakan desert, with a small population (40 million) and generally unpolluted. This large area (about $40 \%$ of Chinese territory) represent only $3.5 \%$ of $\mathrm{NO}_{\mathrm{x}}, 5.0 \%$ of $\mathrm{CO}$, and $10.8 \%$ of NMHC of the total emissions in China. Area2 covers centralEast and Southeast China. The region is economically active with a large population (1053 million), and it is the most polluted area in China; it contributes $81.6 \%$ of $\mathrm{NO}_{\mathrm{x}}, 81.0 \%$ of $\mathrm{CO}$, and $78.2 \%$ of NMHC of the total emissions in China. Area3 covers provinces in the northeast 
of China that are populated and have larger vegetation coverage. The biomass burning from forest is high during summer and autumn. Area3 contribute $14.9 \%, 13.8 \%$, and $11.0 \%$ of the total $\mathrm{NO}_{\mathrm{x}}, \mathrm{CO}$, and $\mathrm{NMHC}$ emissions, respectively. A study has been conducted by Streets et al. (2003), which shows that this area contributes about $15 \%$ of the total biomass burning emissions in China. The surface areas of Area1 and Area2 are comparable; each covers 12 grid boxes in the model domain (T21), whereas Area3 covers 4 grid boxes. These three areas cover $868.3 \times 10^{4} \mathrm{~km}^{2}$, i.e., over $90 \%$ of China's territory.

\section{METEOROLOGICAL DATA}

The general meteorological conditions in winter and summer over China are presented in Fig. 2. The plots show monthly averaged wind fields used in the model for 850,500 , and $200 \mathrm{hPa}$ in January and July. We used diagnostic wind data from the Climate Diagnostic Center (http:// www.cdc.noaa.gov/) to evaluate the data. The ECMWF data used in the model study capture the major transport patterns over this area both in January and July, but underestimate the surface wind speed over the Tibetan Plateau and the Pamir, probably due to the coarse model resolution. Thus the model could underestimate horizontal and vertical transport in this area.

The weather systems over China in wintertime are monotonic and stable, mainly controlled by the Siberian high-pressure systems over the East Asian continent, and also affected by low pressure systems over the North Pacific. Westerly winds are dominating in the middle and upper troposphere and the axis of the westerly jet is along $30^{\circ} \mathrm{N}$ latitude. Since the cold Siberian high pressure system controls East Asia, subsidence of air is prevalent over most of China, except on the western and southwestern side of the Tibetan plateau where the air ascends due to the topographic forcing.

Summertime circulation over China is affected by several weather systems. The summer monsoon is the most important climate feature over East Asia. In the middle and upper troposphere, the South Asia high pressure system controls large areas, westerly winds dominate north of $40^{\circ} \mathrm{N}$ and strong easterlies are found south of the Tibetan Plateau. The locations of these easterlies shift to the north with altitude, the interface of westerly and easterly winds is

Table 2. Emission and population density distribution in China and three sub-areas.

\begin{tabular}{|c|c|c|c|c|c|c|c|c|}
\hline \multirow[t]{2}{*}{ Area } & \multicolumn{2}{|l|}{ Population } & \multicolumn{2}{|l|}{$\mathrm{NO}_{\mathrm{x}}$} & \multicolumn{2}{|l|}{$\mathrm{CO}$} & \multicolumn{2}{|l|}{ NMHC } \\
\hline & $\begin{array}{l}\text { Populatio } \\
\text { n million }\end{array}$ & $\begin{array}{l}\text { Fraction } \\
\text { in China }\end{array}$ & $\begin{array}{l}\text { Emission } \\
\operatorname{Tg}(\mathrm{N})\end{array}$ & $\begin{array}{l}\text { Fraction } \\
\text { in China }\end{array}$ & $\begin{array}{l}\text { Emission } \\
\operatorname{Tg}(\mathrm{C})\end{array}$ & $\begin{array}{l}\text { Fraction } \\
\text { in China }\end{array}$ & $\begin{array}{l}\text { Emission } \\
\mathrm{Tg}(\mathrm{C})\end{array}$ & $\begin{array}{l}\text { Fraction } \\
\text { in China }\end{array}$ \\
\hline Area1 & 40 & $3.4 \%$ & 0.238 & $3.5 \%$ & 5.46 & $5.0 \%$ & 2.37 & $10.8 \%$ \\
\hline Area2 & 1053 & $90.1 \%$ & 5.58 & $81.6 \%$ & 88.3 & $81.0 \%$ & 17.2 & $78.2 \%$ \\
\hline Area3 & 68 & $5.8 \%$ & 1.02 & $14.9 \%$ & 15 & $13.8 \%$ & 2.41 & $11.0 \%$ \\
\hline China & 1168 & $100 \%$ & 6.84 & $100 \%$ & 109 & $100 \%$ & 22.0 & $100 \%$ \\
\hline
\end{tabular}


o) NOx emission over Chino

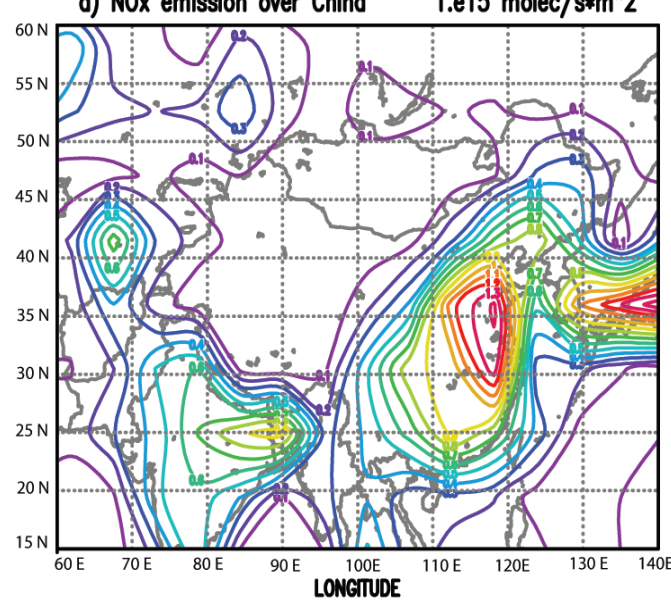

c) NMHC emission over Chino $1 . e 15 \mathrm{molec} / \mathrm{s} * \mathrm{~m}^{\wedge} 2$

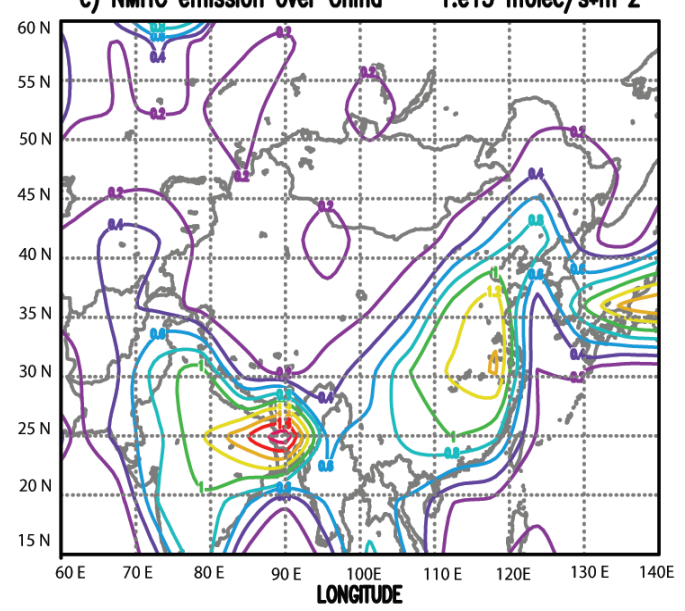

b) $\mathrm{CO}$ emission over China $\quad 1 . \mathrm{e} 15 \mathrm{molec} / \mathrm{s} * \mathrm{~m}^{\wedge} 2$

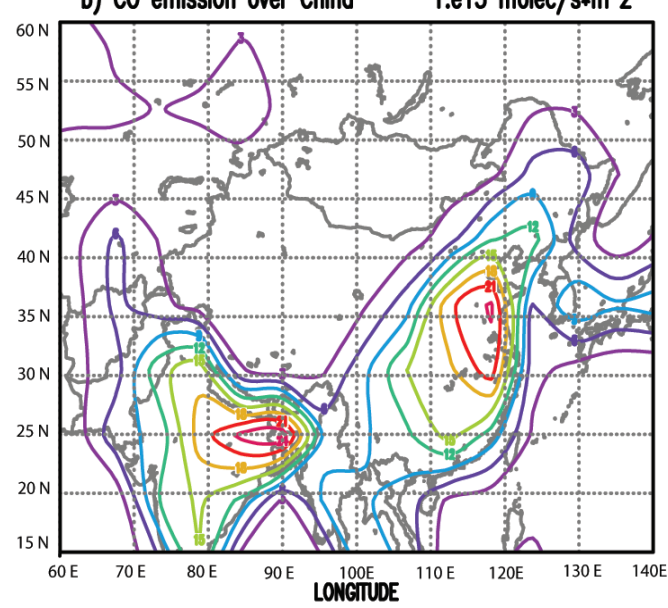

d) China: Population Density

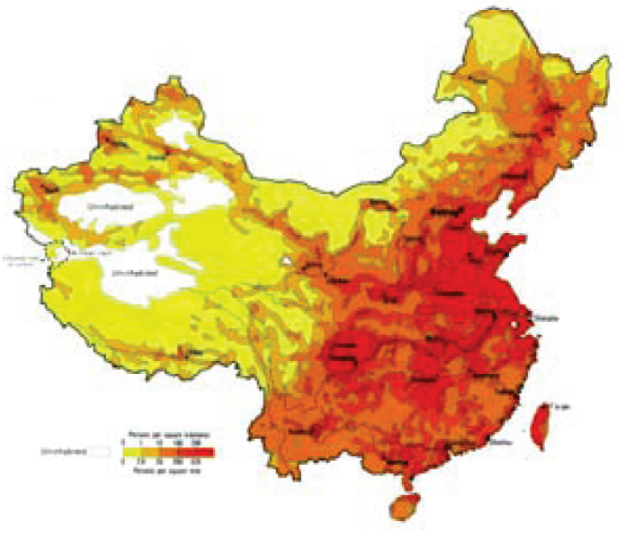

Fig. 1. Surface Emission and Population distribution in China.

around $28^{\circ} \mathrm{N}$ at the $200 \mathrm{hPa}$ level. Close to the surface, the eastern part of China is affected by the East Asia summer monsoon, and the prevailing wind is from the south and southeast (onshore wind). This brings wet and warm marine air to the continent from the India Ocean and the West Pacific, and causes significant precipitation during the summer time and the interface of marine air and continental air occurs near the coast. In western China, the flow converges from surrounding areas towards the Tibetan Plateau, with upward transport from the surface to the free troposphere. Under influence of the low pressure system over the Bengal Bay and the Arabian Sea, southwest wind prevails over large areas south of the Plateau. 

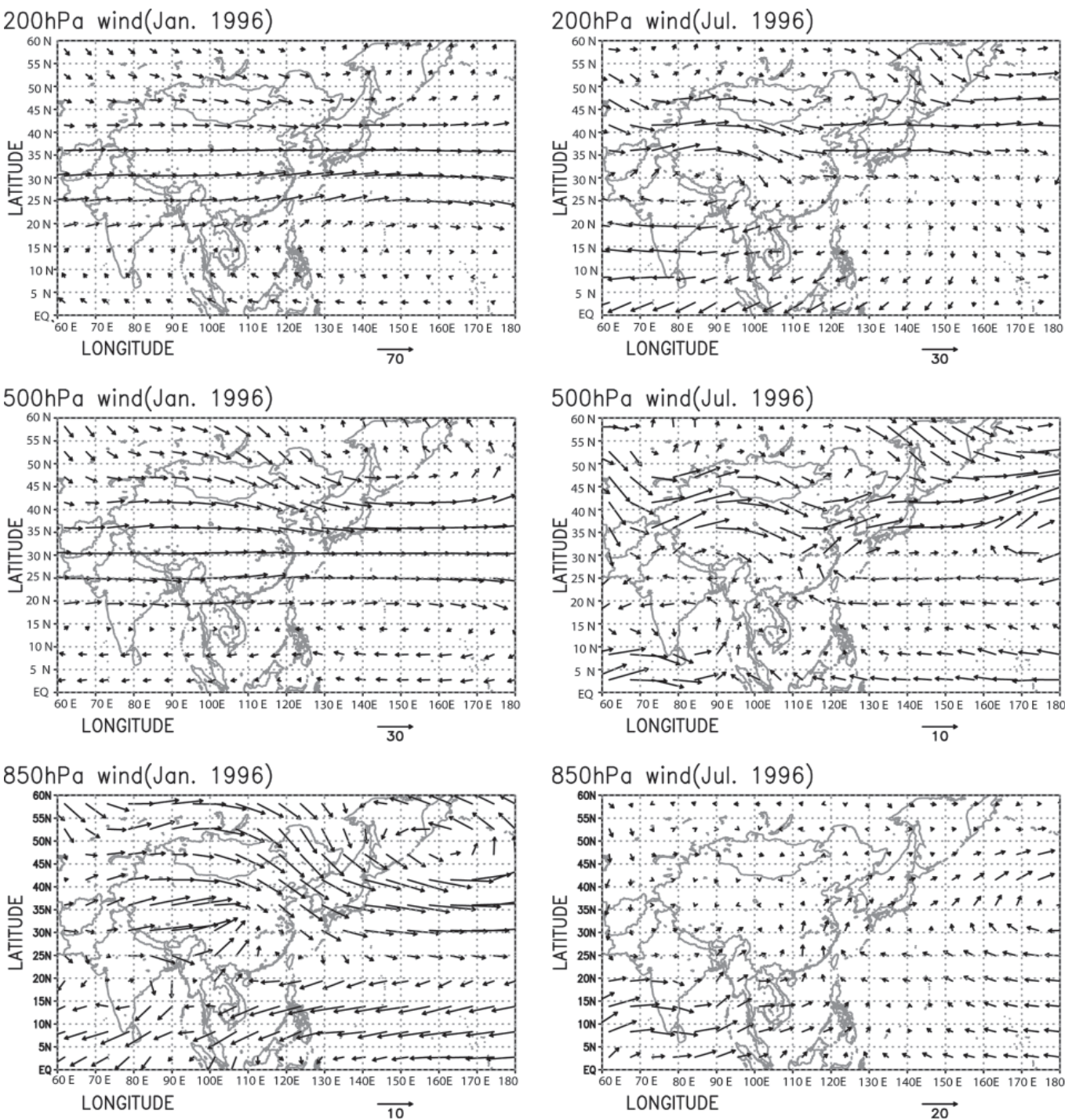

Fig. 2. Simulated average wind fields over China at 200, 500, and $850 \mathrm{hPa}$ in January and July.

\section{EXPERIMENTAL SETUP}

In this work, the model run is setup for year 1996. The model is run for one year with 3 months spin up time (15 month total), and the meteorological data are updated every three hours. The basic time step for the OsloCTM2 model is 1 hour for transport and 15 minutes for 
chemical integrations. The pre-calculated meteorological data from ECMWF are updated every 3 hours in the model.

As discussed in section 3, we have defined three geographical sub-areas in China following the emission distribution and topography (Fig. 3). The budgets of $\mathrm{O}_{3}, \mathrm{NO}_{\mathrm{x}}, \mathrm{CO}$, and $\mathrm{NMHC}$ are set up over those three sub-areas in order to study the production and loss processes for China as a whole and for each sub-area separately. The processes include horizontal transport, stratospheric input, in-situ photochemical production/loss, dry deposition and emission.

\section{OBSERVATION DATA}

Measurement data from China are still very limited. Data from four surface stations (Waliguan, Linan, Longfengshan, and Qindao) in China are available from the project named "The Ozone Change over China and Its Influence on Climate and Environment" (Tang et al. 1995; Xu et al. 1995). The experimental period of the project was August 1994 - May 1995, and species like $\mathrm{SO}_{2}, \mathrm{O}_{3}, \mathrm{NO} / \mathrm{NO}_{2}$, and $\mathrm{NMHC}$ were measured. Data from five other WMO

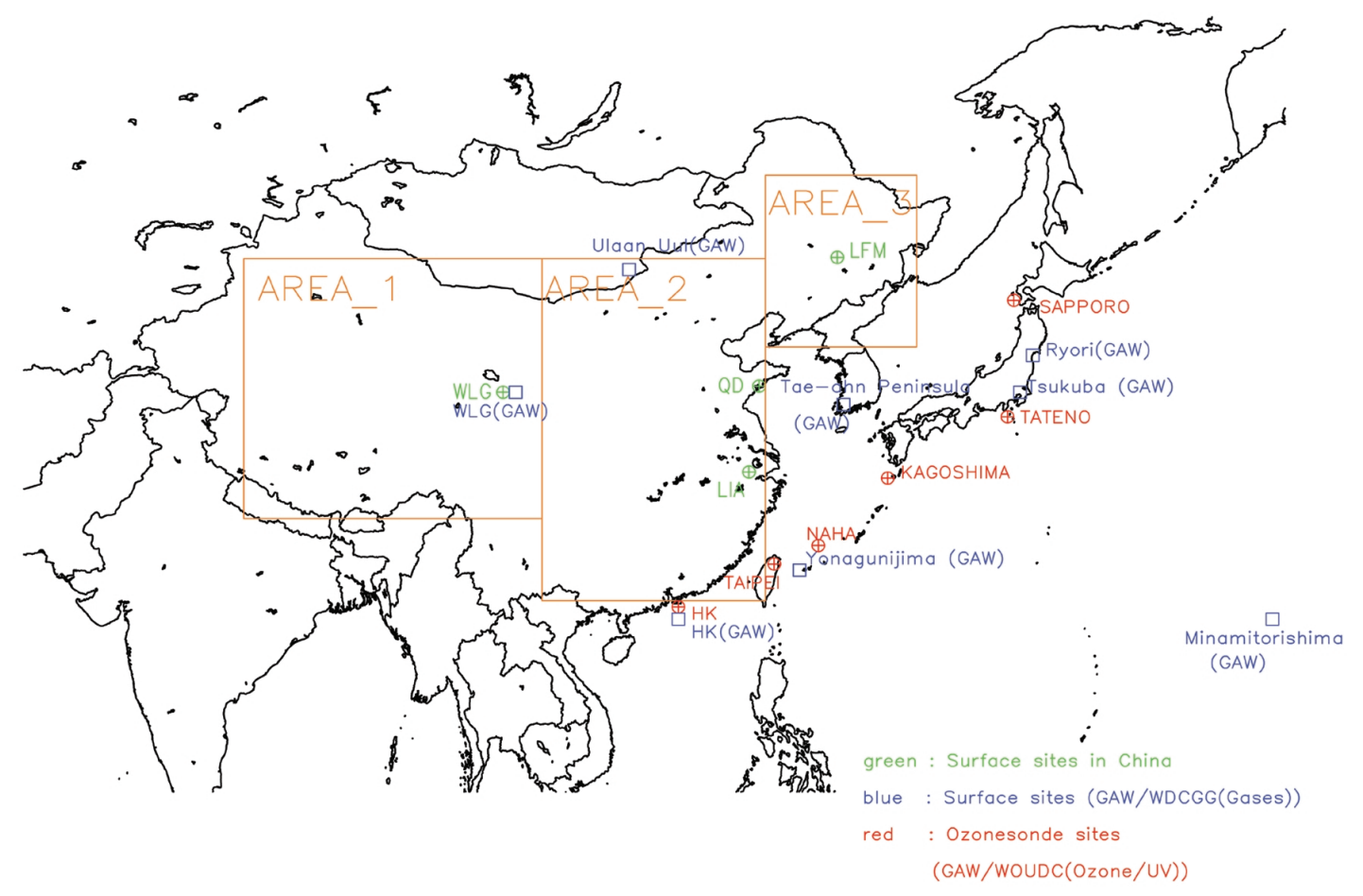

Fig. 3. The location of surface stations and ozonesonde sites, and the regions defined for the budget study (green: surface sites in China; blue: surface GAW sites; red: ozonesonde site). 
Global Atmosphere Watch (GAW) stations (http://gaw.kishou.go.jp/wdcgg.html) are also used, including stations in Japan (Minamitorishma, Ryori), China (Hong-Kong), Korea (Tae-ahu peninsula), and Mongolia (Ulaan Uul). For model validation in the middle and upper troposphere, ozonesonde data from the WMO World Ozone and UV Data Center (http://www. woudc.org/) are chosen to compare with model results. No ozonesonde data are available from inland of China. The six ozonesonde stations we have chosen are located east of China, and the latitude range is large: from $22.3^{\circ} \mathrm{N}(\mathrm{HK})$ in the south to $43.0^{\circ} \mathrm{N}$ (Sapporo) in the north, and in between are Tateno, Kagoshima, Naha, and Taipei. Figure 3 depicts the locations of all stations.

\section{MODEL RESULTS AND COMPARISON WITH MEASUREMENTS}

Since the model resolution (around $500 \times 250 \mathrm{~km}$ at middle latitude) is coarse for comparison with measurements at a specific time and location, exact spatial and temporal match of species are not expected. It is more suitable to use the monthly average results than to use daily or hourly results to compare with measurements, so the analysis of model results and measurements are all based on monthly averages.

\subsection{Seasonal Ozone Distribution Close to Surface}

Figure 4 shows the monthly average of the surface ozone concentration distribution simulated over China and countries in Southeast Asia and the West Pacific (January, April, July, and October). Measured surface ozone values are also marked on the plots. Figure 4 clearly shows that the locations of the ozone maximum follow the variation in solar radiation from season to season. The highest ozone levels are found between $10-20^{\circ} \mathrm{N}$ latitude in January, between $30-40^{\circ} \mathrm{N}$ latitude in July, and $15-30^{\circ} \mathrm{N}$ latitude in April and October. There are two major anthropogenic emission areas (see Fig. 1) in East Asia; one is located in East China; another is in Northeast India, close to the Chinese border. Enhanced ozone levels are not always co-located with the emission maximum, because of transport and also because of the nonlinear production of ozone.

\subsubsection{Ozone Levels during the Winter Months}

Low solar radiation and low temperatures at mid-latitude of Asia in winter lead to less ozone photochemical production. This is the main reason why the areas with large emissions in the eastern part of China only have ozone levels from 25 to $35 \mathrm{ppbv}$. In the wintertime, subsidence over the continent also keeps local emissions in the boundary layer. Titration is playing an important role for $\mathrm{O}_{3}$ loss, therefore, the lowest $\mathrm{O}_{3}$ of 15 - 20 ppbv are found near the locations of the largest $\mathrm{NO}_{\mathrm{x}}$ emissions. This distribution and these ozone levels agree well with previous studies by Mauzerall et al. (2000) and by Zhao et al. (2006). They both used the global CTM MOZART to study the topospheric ozone characteristics over this region. On the other hand, high surface ozone levels ( $>40 \mathrm{pppbv}$ ) are found in Southwest China (Yunnan, Sichuan province) during the winter months, when the prevailing winds at the surface level are from the southwest. Surface winds are eastwards in northern China, Japan and Korea, they 

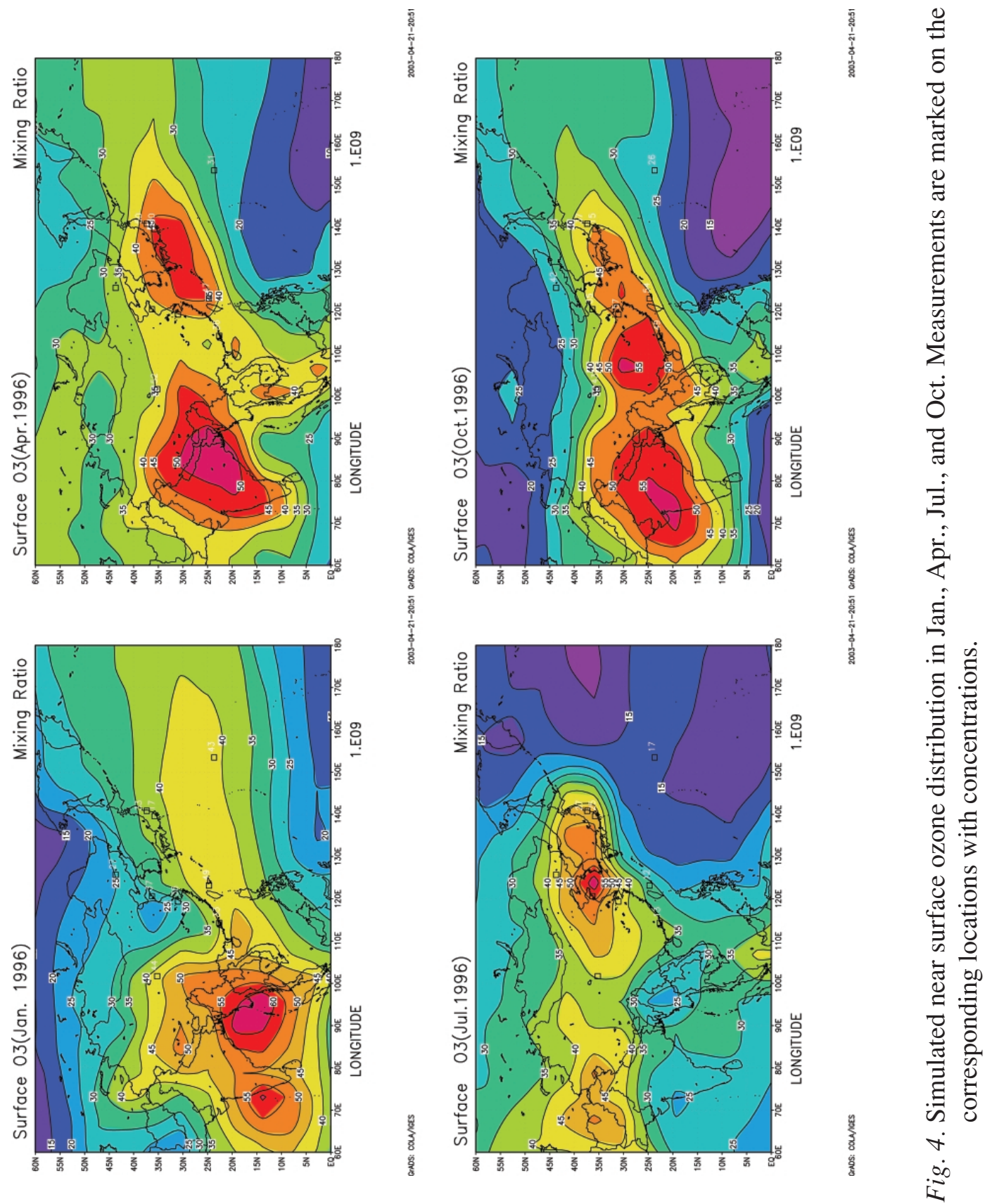
flow clockwise out to the sea and move southwards along the coast into the South China Sea. This wind pattern brings large amounts of surface pollutants originating in the boundary layer of eastern China to the West Pacific, the South China Sea, and the Indian Ocean. The pollutants are oxidized along the way to the ITCZ, and after rising in the ITCZ the pollutants flow back into China at higher altitudes. The winds bring emissions from countries south of China, which have experienced higher solar radiation. High ozone levels, with surface values from 35 to $50 \mathrm{ppbv}$, are found over the Tibetan Plateau and its surrounding areas (on average about $3000 \mathrm{~m}$ asl) for different reasons. The high ozone levels over this region represent the ozone levels in the free troposphere because of the height of this region. The high ozone center over the Indian Ocean is mostly caused by large emissions from the India peninsula, and also partly contributed to by emissions from other regions in Asia. Phadnis et al. (2002) studied the pollution from South and Southeast Asia during the winter-spring monsoon, and showed that surface emissions from South and Southeast Asia, could contribute over $30 \%$ of the $\mathrm{O}_{3}$ in the boundary layer over the Indian Ocean.

\subsubsection{Ozone Levels during the Summer Months}

High surface ozone levels are found between $35-40^{\circ} \mathrm{N}$ in summer, connected with strong solar radiation and anthropogenic emissions. The highest ozone levels are found over the Chinese Yellow Sea, between China, Japan and Korea. Fast photochemical oxidation combined with efficient deposition, a deep boundary layer, deep convection, and mixing with low latitude marine air, limits build up of ozone during summer. So the highest ozone level is approx. $50 \mathrm{ppbv}$ over the very polluted continent. Similar numbers of about $40-50 \mathrm{ppbv}$ are simulated by Zhao et al. (2006), and about 45 ppbv by Mauzerall et al. (2000). A peak ozone level around 60 ppbv over the ocean was found because of the lower dry deposition of ozone over the water. This feature is not shown in studies of Mauzerall and Zhao, maybe because of the different deposition scheme in the model. Ozone levels along the coast of the South China Sea are about 35 ppbv, despite the large emission in this area. Mixing with clean marine air that arrives with the summer monsoon causes these lower ozone levels along the coast. In western China, summer surface ozone levels are very much affected by background levels, which are high over this area, since the body of Tibetan Plateau is above 3000 on the average. The levels over the Tibetan Plateau (level 7) are above 50 ppbv. The study of Yang et al. (1999) has shown that the ozone levels over the Tibetan Plateau are strongly affected by air aloft in summer, because of strong vertical mixing.

\subsubsection{Ozone Levels during Spring and Autumn}

In spring and in autumn, high surface ozone levels are found at similar latitudes, but the locations are different because of different meteorological conditions during these two seasons. East Asia is characterized by strong continental outflow over the year, especially for north of $30^{\circ} \mathrm{N}$. The meteorological conditions over China both in spring and autumn are characterized by the positions of westerlies and the positions of the subtropical high. The spring has a similar pattern as the winter, but westerly winds get weaker and move northwards, even though the 
westerly jet still has a wind speed of about $50 \mathrm{~m} \mathrm{~s}^{-1}$ in this period. Combined with the rapidly increased photochemical activities over East Asia, the spring is the season that experiences the maximum offshore flow from Asia. The model results for April indicates that the largest outflow contribution to the West Pacific is found in spring with high values above 45 ppbv. Surface $\mathrm{O}_{3}$ reaches 35 ppbv over the large area of the West Pacific between $25-35^{\circ} \mathrm{N}$ because of the continental outflow. The highest ozone levels over the continent (about $55 \mathrm{ppbv}$ ) are found in October, concord with the polluted area in eastern China. In autumn, the subtropical high can reach its northernmost position around $40^{\circ} \mathrm{N}$, and the westerly jet is weak and far more north compared to the spring, with cloudless conditions beneficial for surface ozone production over the continent. The weather is characterized by warm and sunny days during this period. The studies by Mauzerall et al. (2000) and Zhao et al. (2006) indicated strong offshore export from this region as well.

\subsection{Monthly Variation of $\mathrm{O}_{3}, \mathrm{NO}_{\mathrm{x}}$, and $\mathrm{CO}$ at Surface Stations}

Figure 5 gives a comparison of model simulated monthly variations with observations for $\mathrm{O}_{3}, \mathrm{NO}_{\mathrm{x}}$, and $\mathrm{CO}$ at 9 surface stations.

\subsubsection{Two Global Baseline Stations}

Both Waliguang (WLG) and Minamitorishima are global baseline stations, and are expected to observe background levels representative for large regions. The model gives good results at these two stations, especially for Minamitorishima. At this site both concentration levels and monthly variation agree with measurements, the differences are within $20 \%$ for $\mathrm{O}_{3}$ and $10 \%$ for CO. The observed levels and variations reflect general meteorological conditions, the station receives air masses transported from the continent in the winter and from the ocean in the summer, and there are no local emission influences. WLG is a high altitude station, representing ozone background levels in the free troposphere. Yang et al. (1999) have showed that the surface ozone at the WLG station is highly affected by ozone levels aloft during summer because of strong vertical transport. Our study also shows that the transport is the most important process for this area. Ozone levels vary between 40 and 60 ppbv while model values are in the range $45-65 \mathrm{ppbv}$ (model level 7, about $2.6 \mathrm{~km}$ ). The temporal variation agrees with measurements, but overestimates the ozone values in wintertime. Both model and observations show lower ozone levels during the winter, and increasing from the spring, the peaks are found in August. The ozone observed gave ozone increasing in spring, which is higher than the model simulated result; this maybe caused by the lower wind speed in the model. The measurements of ozone in June and July are absent, and measured $\mathrm{NO}_{\mathrm{x}}$ and $\mathrm{NMHC}$ levels at WLG are higher than model results during this period. The higher levels of $\mathrm{NO}_{\mathrm{x}}$ and NMHC at Waliguan can possibly be caused by influences from the local sources in the summertime. Wang et al. (2006) argued that the measured high $\mathrm{NO}_{\mathrm{y}}$ and $\mathrm{NO}$ are emissions from soils related to biomass waste at WLG, because of the cattle grazing activity in this region. The underestimated values in the model maybe ascribed to underestimated emissions over that remote area. 


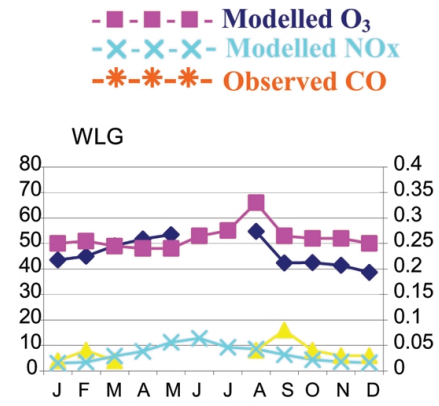

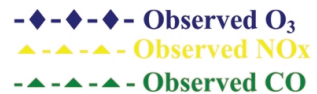

LFM
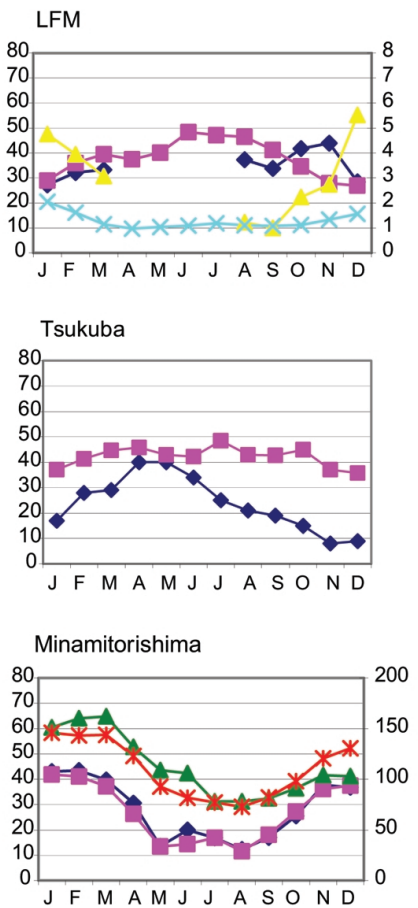

(unit : ppbv)
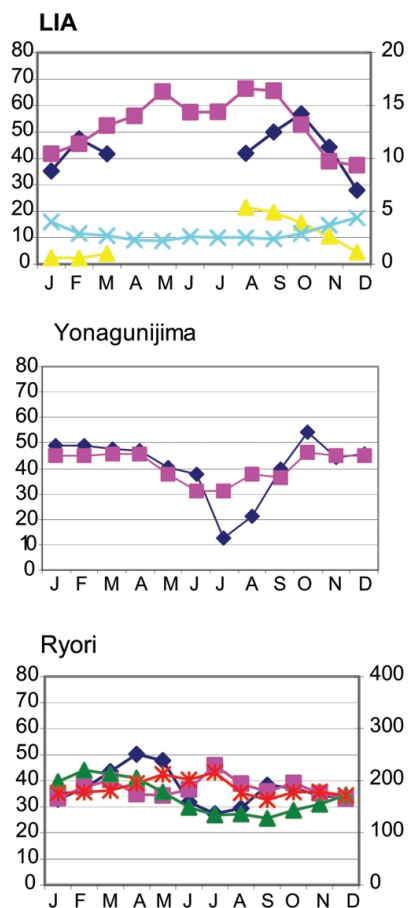

Fig. 5. Monthly variation of model results and observation at surface stations (unit : ppbv).

\subsubsection{Continental Stations in China}

The LIA station is a regional background station in East China. This is a very populated area. Several cities are located northeast (e.g., Shanghai) and east (Linan) of LIA station. Monthly measured values of ozone at LIA are in the range $20-65 \mathrm{ppbv}$, and in the range $25-55 \mathrm{ppbv}$ for model results. Observed $\mathrm{NO}_{\mathrm{x}}$ levels vary between 2 - $22 \mathrm{ppbv}$, which shows the influence of local emissions, especially during the summer. The simulated ozone monthly variation and levels agree quite well with observations from late autumn to early spring. The model shows ozone levels in June and July that are lower than in May and August, which is caused by the summer monsoon, when the prevailing wind from the southeast brings clean oceanic air to the site. The increased height of the boundary layer in the summer also dilutes ozone close to the surface. The surface observation data show the influences from cities in the summer and early autumn. The combination of lower ozone and higher $\mathrm{NO}_{\mathrm{x}}$ levels suggested that the air parcels arrived with the monsoon. Therefore, this station may not be suitable for representing general conditions over this region for the summer and early autumn months. 
The LFM station is a regional background site in northern China, located on the top of the Longfeng Mountain, surrounded by forest, thus natural emissions are likely to be important during the growing season. There is good overall agreement between observed and modeled results. The range of ozone levels for this site is $25-50 \mathrm{ppbv}$, and the differences are limited to $15 \%$ over the period when observations are available. Both model results and measurements show low ozone levels in winter, and increasing from spring. The modeled ozone peak is found in summer, whereas measurements are not available during the summer months at LFM. The observed ozone peak was found in October and November, about 16 ppbv higher than the model result. The measured high ozone levels in autumn seem to be caused by local natural emissions. Measured NMHC (five-day average) shows a very high value of about $1240 \mathrm{ppbv}$ in August, and $840 \mathrm{ppbv}$ in October, while the model simulated monthly average levels are 15 and $11.6 \mathrm{ppbv}$, respectively. Xu (1995) evaluated the measurements by checking the contributions from different sources, and concluded that NMHC at LFM was contributed both by anthropogenic and natural emissions, but there was no conclusion as to whether that high emission case happened only in this period, because there was only a few days of measurements and also a lack of data from previous years. Since the biomass emission from forest is high during autumn, this high NMHC emission episode may not be a bona fide occasion. The weather conditions in autumn over this area are characterized by clear skies, strong radiation and stagnant high pressure systems, which favour accumulation of ozone when precursors are present. $\mathrm{NO}_{\mathrm{x}}$ levels given by the model are about $50 \%$ of the measurements.

QD station is a Chinese EPA background site for Qingdao city, and is located $16 \mathrm{~km}$ southeast of the city. The site is strongly influenced by local emissions, especially in wintertime when northwest and west winds are dominant. $\mathrm{O}_{3}$ concentrations at QD station vary from 20 - 60 ppbv for observations, and 20 - 55 ppbv for model results. Measured $\mathrm{NO}_{\mathrm{x}}$ levels are between 25 - 55 ppbv, whereas model results are about $2-6$ ppbv. Both model results and observations have the same pattern for ozone levels, with low values in winter that begin increasing from spring. No NMHC observation are available at this site, but agreement of ozone levels and large differences in $\mathrm{NO}_{\mathrm{x}}$ levels is a very good example for showing the non-linear chemical production of ozone. The model results show high ozone levels (about $50 \mathrm{ppbv}$ ) from May to September. Although observations are absent during this period, it is likely that high pollution leads to ozone increasing during this period.

\subsubsection{Stations along the Coast}

Model results at the HK and Yonagunijima agree well with measurements most of the year except during the summer months. From July to August, ozone levels in the model are about 33 - 39 ppbv and measured values are about $12-13$ ppbv at HK and $12-22$ ppbv at Yonagunijima. Measured $\mathrm{CO}$ levels at $\mathrm{HK}$ are less than 150 ppbv during the same period, shows the air mass is from ocean. In the summertime, the prevailing winds for these two stations are from south and southeast, mostly controlled by clean and wet marine air. The clean air masses arriving at $\mathrm{HK}$ and Yonagunijima with the summer monsoon can explain the overestimated ozone levels at those two sites. The differences between the model and measurements may be caused by the model resolution, since it is difficult to define the interaction 
of continental air with marine air in the model. Increased model resolution is expected to improve simulations at these locations. Ozone levels during winter at Yonagunijima are generally higher than ozone levels at other stations in east of China, because this site is more affected by trapped emission in the boundary layer from eastern China during this period. The model captures this feature very well. The Tsukuba station is located $60 \mathrm{~km}$ northeast of Tokyo. Prevailing winds are from the west during winter months and from the southeast in spring and summer. This could bring polluted air to this site, and the role of biomass burning in southern China during the spring and summer could be important. The Ryori station is located at $39^{\circ} \mathrm{N}$ and prevailing winds are from west and northwest in the winter, spring and late autumn, and from southwest in the summer. $\mathrm{O}_{3}$ measurements reach a maximum in April and May at those two sites, and then gradually decrease at Tsukuba until winter, whereas Ryori shows a second peak in September and October. The differences at those two sites show that this area is sensitive to the strength and position of the westerlies in autumn, when the westerlies are shifting to the north.

In summary, the model gives reasonable results for ozone levels and distribution close to the surface. The simulations at the global baseline stations Minamitorishima and WLG show that the model is able to perform good simulations for background levels and free tropospheric ozone levels. For Chinese regional stations LFM and LIA, which are strongly influenced by local sources in certain periods, the model gives reasonable levels and monthly variations. Some discrepancies with measurements are found, local anthropogenic or natural emissions have strong influences on those two stations. For the station QD, as a background site of QD city, the model gives results that are comparable with measured $\mathrm{O}_{3}$ levels. However, the difference between modeled and measured $\mathrm{NO}_{\mathrm{x}}$ is large, indicating the strong influence from anthropogenic activities. The model has difficulty simulating ozone levels during the summer for stations are strongly influenced by the summer monsoon, as is the case with station HK and Yonagunijima. The model overestimates the levels of pollutants in summer months. This could be the result of coarse model resolution, or the model underestimating subscale processes, which can distribute species in a short time. The model agrees well with observation at Yonagunijima during the winter and spring, showing that the model can capture the transport pattern over eastern China along the coast. The differences at stations Tsukuba and Ryori show that the stations located in this region are sensitive to westerlies. It seems difficult for the model to capture the locations of westerlies when they shift.

\subsection{Ozone Vertical Profiles and Ozone Soundings}

Vertical ozone measurements are not available inland of China. A total of six ozonesonde stations (see Fig. 3) are chosen for model validation, including one Chinese coastal site (HK), and 5 other sites near China's coast. Most data presented here are from 1996. Data from January, April, July and October represent four seasons, and if more than one ozone sounding is available for any particular month, we use the average value of all the soundings from that month. There is no Oct. 1996 data from any of the stations; we use the data from 1995 instead. For station HK and Taipei we used data from 2000. Figure 6 shows the ozone vertical profile from the surface to $200 \mathrm{hPa}$ at six stations and the model results. 

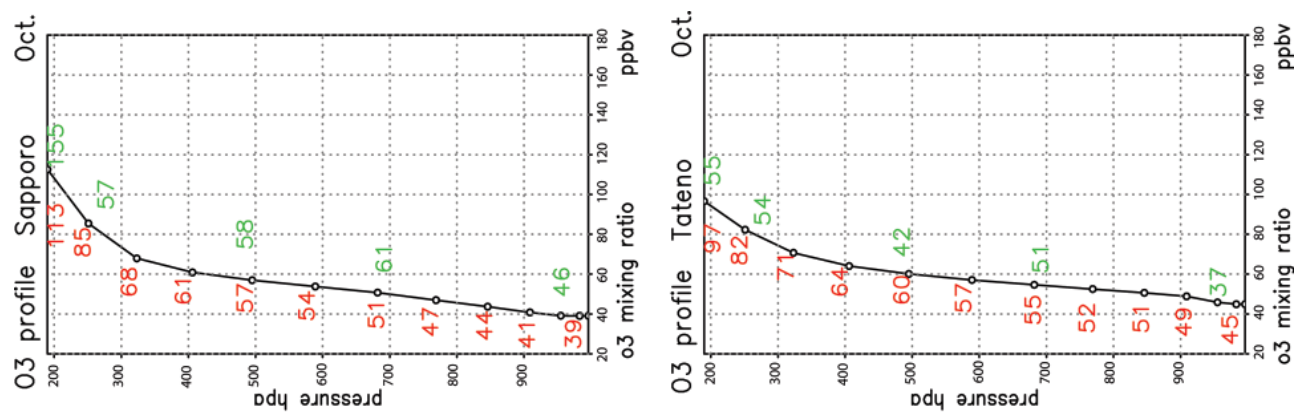

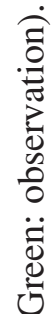
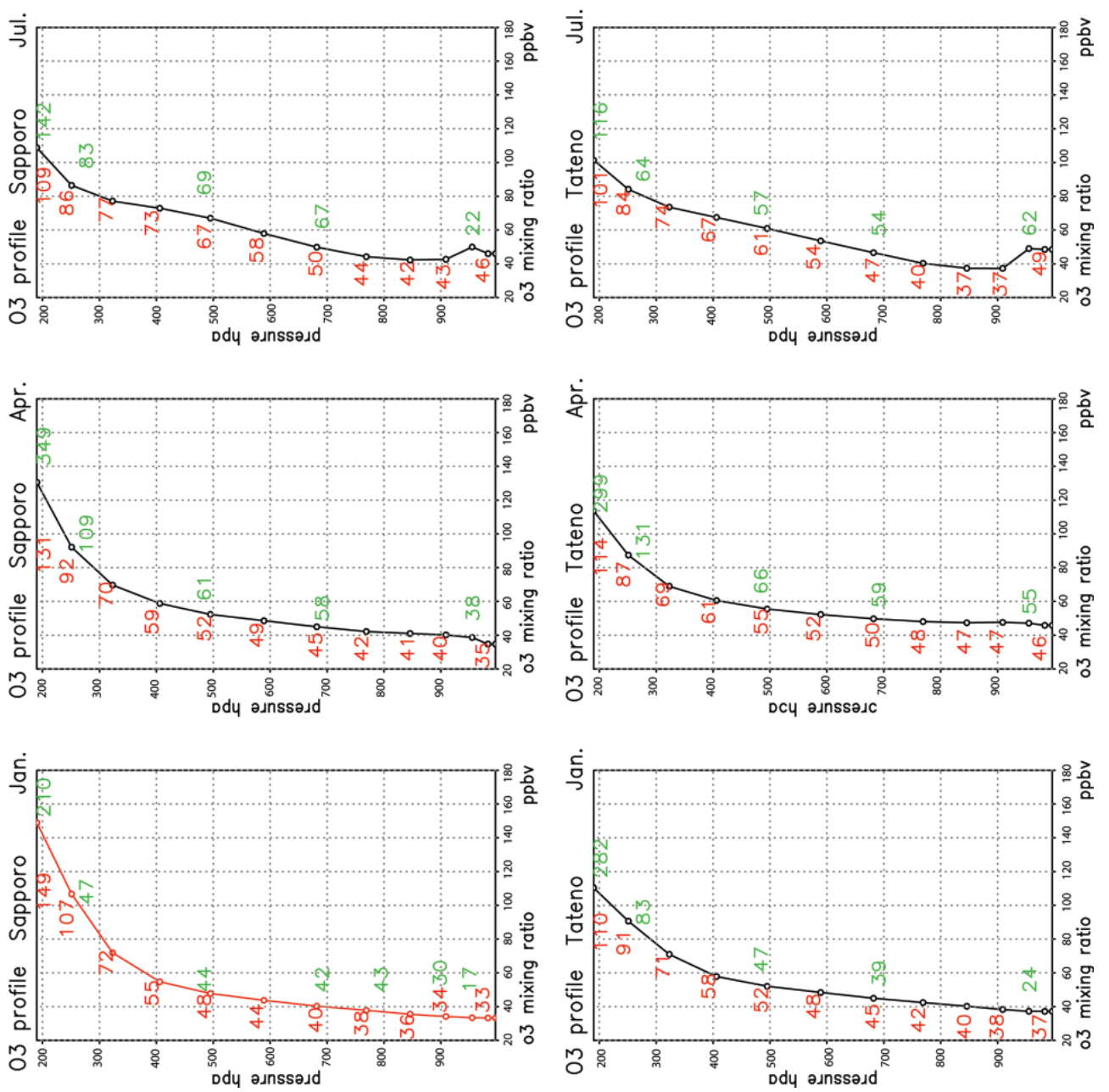

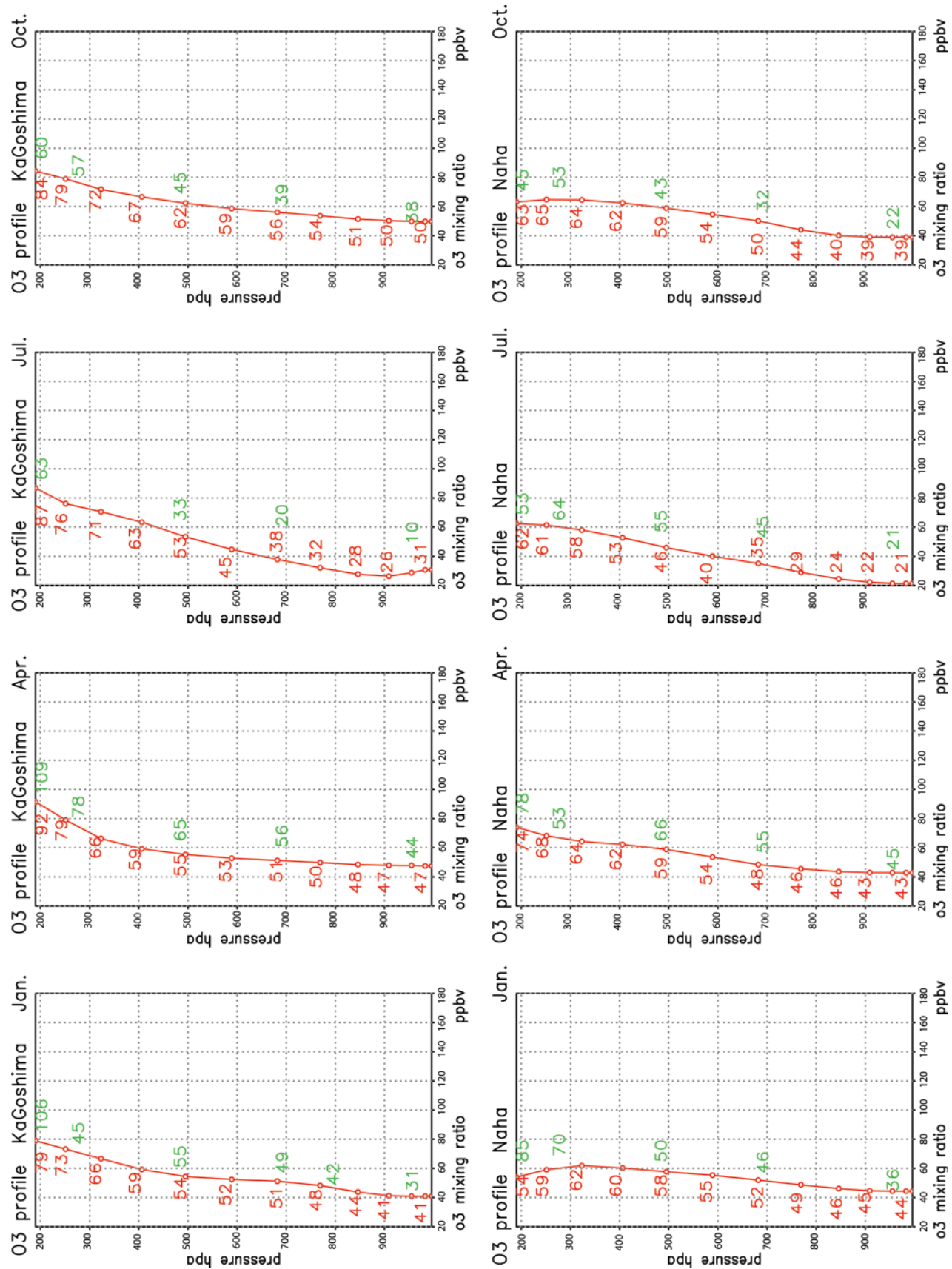

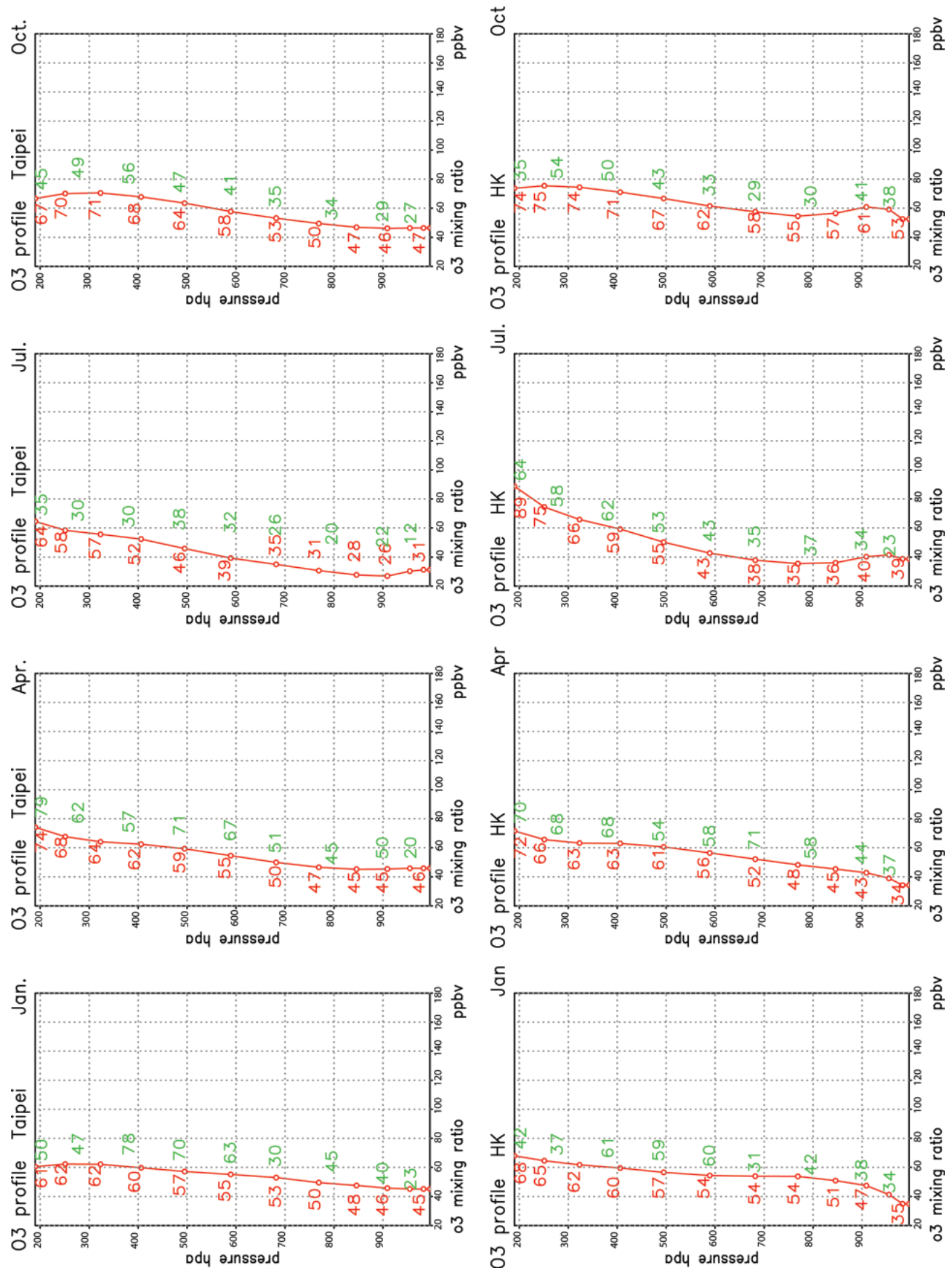

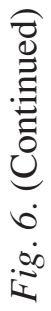




\subsubsection{Stations Located North of $30^{\circ} \mathrm{N}$}

For Sapporo, Tateno and Kagoshima, model simulated values agree well with the ozonesonde data in the lower and middle troposphere in winter and spring, but underestimate the ozone values in the upper troposphere above $300 \mathrm{hPa}$. The differences between measurements and model results in the upper troposphere in spring are larger than in winter, and increase with increasing latitude and altitude. These three stations are controlled by strong westerly jets both in winter and spring, while photochemical activity is depressed by low radiation and temperature. Vertical convection is not important in winter and subsidence is dominant under the Siberian high pressure systems. Bachmeier et al. (1996) have described the stratosphere/troposphere exchange in the vicinity of jet streams. High ozone injections from the stratosphere into the troposphere are mostly found with subsidence inversions under deep anticyclonic systems. Stratospheric input is therefore important during this period, and both model and measurements show rapid increases at the levels above $400 \mathrm{hPa}$. The largest deviation is found for Sapporo in April at about $200 \mathrm{hPa}$. The measured value is $218 \mathrm{ppbv}$ higher than model results, which is twice the model result, whereas the difference at $300 \mathrm{hPa}$ is only about 29 ppbv, 30\% of the model result. The increase in Sapporo is much larger than in Kagoshima because of its higher latitude. Underestimates of ozone levels in the upper troposphere in the model can be caused by underestimated ozone flux from the stratosphere, which is fixed at $540 \mathrm{Tg} \mathrm{yr}^{-1}$ in the top of the model layer. During the summer months, the model gives good results in the middle troposphere, but still underestimates levels at $200 \mathrm{hPa}$. The model results close to the surface are more affected by local photochemical ozone production and transport.

\subsubsection{Stations Located South of $30^{\circ} \mathrm{N}$}

Model results at Naha, Taipei and HK generally agree well with observations for all seasons, and the differences are less than $30 \mathrm{ppbv}$ for all three stations at all altitudes from the surface to about $200 \mathrm{hPa}$. The results at Naha show similar underestimates at $200 \mathrm{hPa}$ as the stations located north of $30^{\circ} \mathrm{N}$ in winter and spring since the influence of stratospheric input is smaller at this site. All three sites are strongly influenced by monsoons and typhoons during the summer, which can explain overestimates of the model results during this period. Despite ozone overestimation close to the surface, the model results agree quite well with measurements above $850 \mathrm{hPa}$ at HK. Since data for Taipei and HK is from 2000, comparison with model results from 1996 might not be so representative.

\section{OZONE BUDGETS FOR CHINA}

For a more explicit study of tropospheric ozone production and loss processes over China, we have defined three sub-areas for the budget study based on China's emission and population distribution. The tropopause height is calculated at the level where ozone level reaches 150 ppbv. Figure 7 shows the monthly variation of different processes of $\mathrm{O}_{3} / \mathrm{CO} / \mathrm{NO}_{x} / \mathrm{NMHC}$ budgets for the three sub-areas and for whole of China. Processes include: transport, net chemical production $\left(\mathrm{P}_{\text {chem. }}-\mathrm{L}_{\text {chem. }}\right)$, dry deposition, stratospheric ozone input, and emissions of primary compounds $\mathrm{NO}_{x}, \mathrm{CO}$, and $\mathrm{NMHC}$ in the troposphere. 
Terr. Atmos. Ocean. Sci., Vol. 18, No. 3, August 2007
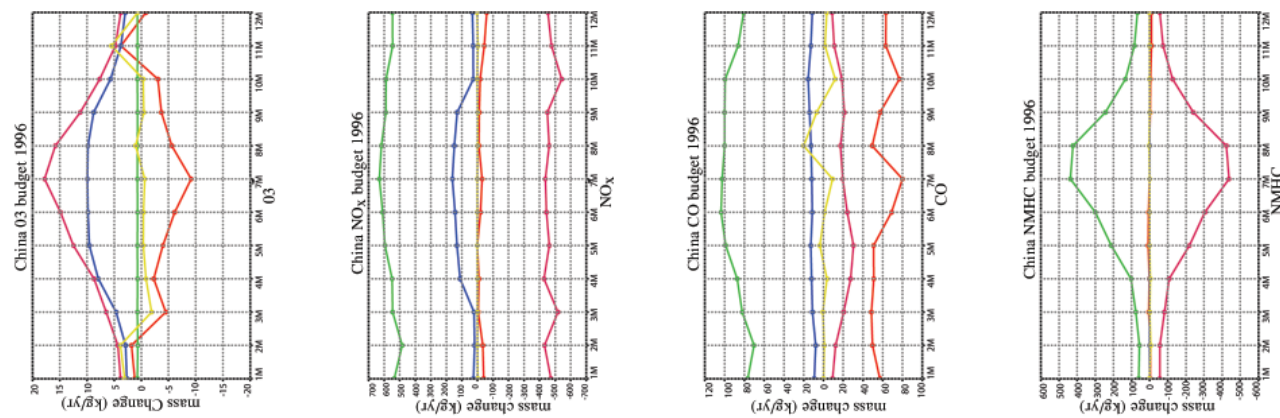

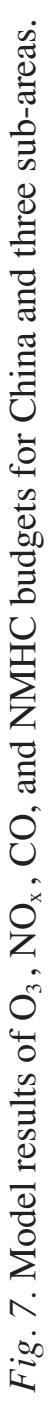
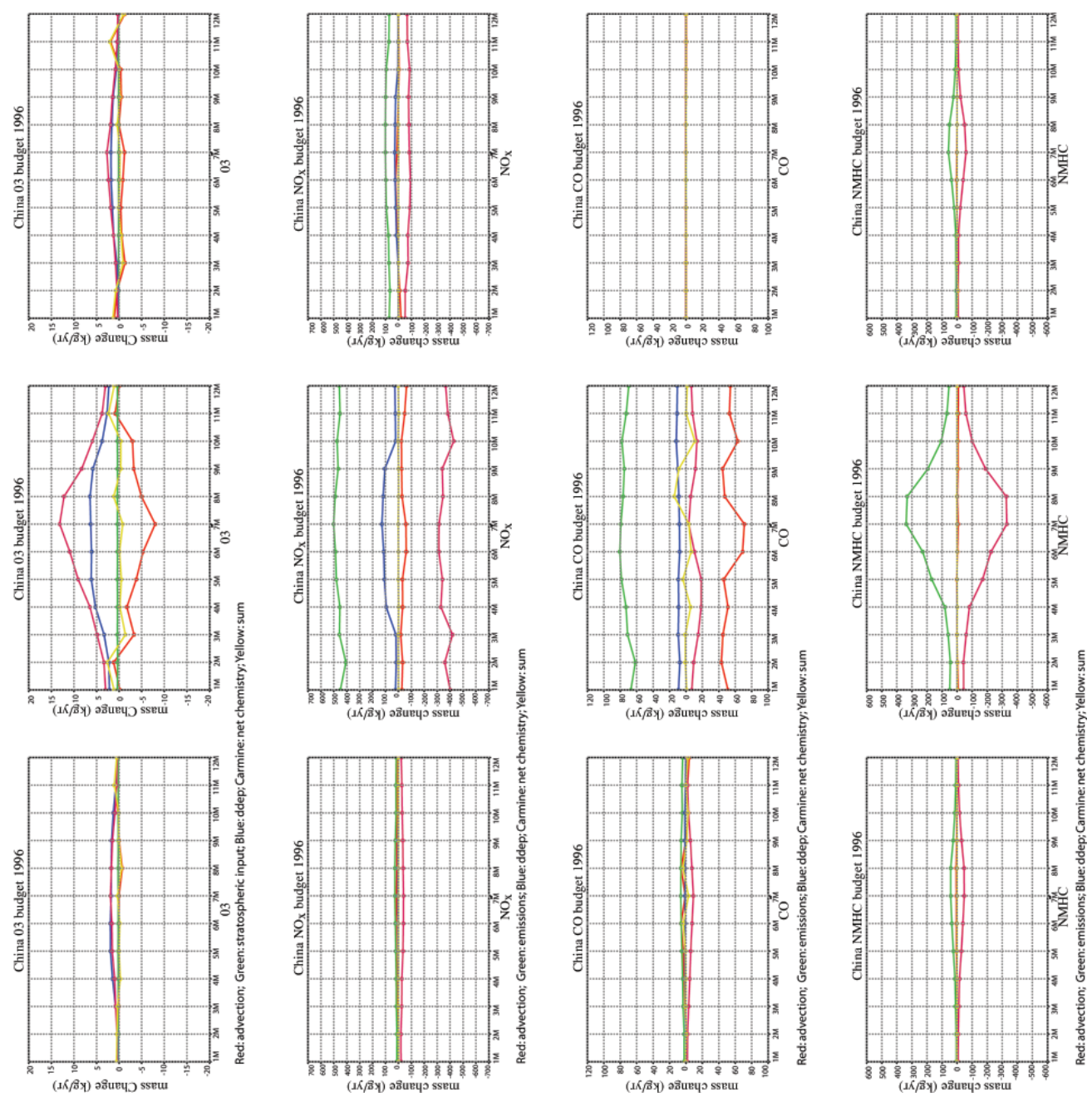


\subsection{Monthly Variation}

For all species, a clearly identified feature is the large contribution from Area2 to the ozone budgets. On average, Area 2 accounts for about $65 \%$ of the tropospheric net photochemical production over China, 55\% of the dry deposition loss, and above $60 \%$ of the net ozone export from China over a year. This is not surprising since more than $80 \%$ of the emissions in China are from Area2.

Model simulated ozone net chemical production over China is $432.6 \mathrm{Gg}_{\text {day }}{ }^{-1}$ during summer, more than four times the value in wintertime. Increased ozone net chemical production is mainly offset by increased dry deposition. The stratospheric input is low compared to the chemical production in the summer months, but it is important during winter and spring when the ozone chemical production is low compared with dry deposition. China is a net ozone producer over the year, most $\mathrm{O}_{3}$ is produced in Area2. Chemical ozone production is always smaller than dry deposition in Area1, therefore the stratospheric input is always important for tropospheric ozone in this area. The dry deposition in Area3 is very important, about $80 \%$ of the chemical production is lost to the surface in this area.

$\mathrm{NO}_{\mathrm{x}}$ emissions are mainly lost by chemical destruction inside this large area, and dry deposition is also important from spring to autumn during the growing season. The transport term in/out of the region is very small because of the large area and the short lifetime of $\mathrm{NO}_{\mathrm{x}}$ against chemical loss. According to the model results, less than $4 \%$ of the $\mathrm{NO}_{\mathrm{x}}$ load is exported from China. $\mathrm{CO}$ budgets are different to $\mathrm{NO}_{\mathrm{x}}$ budgets, because of CO's longer chemical lifetime, so the loss term is determined by transport and chemical destruction together. Concerning contribution to the global CO budget, China is a net exporter of CO as well. About $199 \mathrm{Gg}$ day $^{-1}$ (66.7\% of total emissions) of CO is exported from China. Zhao et al. (2006) have given similar results, namely that less than $10 \%$ of the $\mathrm{NO}_{\mathrm{x}}$ is exported from Eastern China and that about $60 \sim 70 \%$ of the $\mathrm{CO}$ is exported. NMHC production and loss strongly depend on the season, and emissions increase in spring and decrease during autumn. The highest emissions are found in summer with contributions from both anthropogenic and natural sources. Since most NMHC are chemically active, and there is no dry deposition loss, NMHC emissions are mainly offset by chemical loss (95.4\%) in the area. Only a very small amount of NMHC (less than 5\%) has a longer lifetime and can be exported from China.

\subsection{Ozone Budget for the Selected Areas}

Table 3 shows the averaged tropospheric $\mathrm{O}_{3}$ budget over three sub-areas and for the whole of China for the four seasons: Besides other processes mentioned, the sum is the total tendency for the studied area.

\subsubsection{Area1}

Area1 covers western China. Horizontal transport is the largest process during winter months, because of transport with the strong westerly wind. Ozone exported to the east is mainly compensated by imported ozone from the countries south of China. In Area1, the net chemical production in the troposphere is always smaller than the dry deposition over a year, 
Table 3. Model results of $\mathrm{O}_{3}$ budgets for three areas and China for 1996.

\begin{tabular}{|c|c|c|c|c|c|}
\hline & Processes & Area1 & Area2 & Area3 & China \\
\hline \multirow{7}{*}{$\begin{array}{l}\text { Winter } \\
\text { (DJF) }\end{array}$} & Horizontal transport & -15.2 & -44.4 & -74.2 & -133.8 \\
\hline & $x$ direction & -643.0 & -1181.1 & -198.2 & -2022.3 \\
\hline & $y$ direction & 627.8 & 1136.7 & 124.0 & 1888.5 \\
\hline & Stratospheric input & 17.3 & 16.8 & 6.9 & 41.0 \\
\hline & Dry deposition & -20.7 & -58.1 & -6.85 & -85.9 \\
\hline & Net chemistry & 16.6 & 75.1 & 8.64 & 100.5 \\
\hline & Sum & -6.2 & -10.6 & -65.5 & -78.2 \\
\hline \multirow{7}{*}{$\begin{array}{l}\text { Spring } \\
\text { (MAM) }\end{array}$} & Horizontal transport & -41.3 & -27.1 & -13.3 & -81.7 \\
\hline & $x$ direction & -578.3 & -913.4 & -79.8 & -1571.5 \\
\hline & $y$ direction & 537.0 & 886.3 & 66.5 & 1489.8 \\
\hline & Stratospheric input & 18.2 & 17.6 & 7.5 & 43.3 \\
\hline & Dry deposition & -65 & -121.9 & -34.0 & -221.1 \\
\hline & Net chemistry & 47.5 & 169.4 & 37.9 & 254.8 \\
\hline & Sum & -40.6 & 38.0 & -1.9 & -13.7 \\
\hline \multirow{7}{*}{$\begin{array}{l}\text { Summer } \\
\text { (JJA) }\end{array}$} & Horizontal transport & -4.8 & -114.6 & 0.6 & -118.8 \\
\hline & $x$ direction & -36.8 & -326.1 & -55.1 & -344.4 \\
\hline & $y$ direction & 32.0 & 211.5 & 55.7 & 270.2 \\
\hline & Stratospheric input & 16.3 & 16.1 & 4.4 & 36.8 \\
\hline & Dry deposition & -80.8 & -150.1 & -52.4 & -283.3 \\
\hline & Net chemistry & 72.1 & 294.5 & 66.0 & 432.6 \\
\hline & Sum & 2.8 & 45.9 & 18.6 & 112.3 \\
\hline \multirow{7}{*}{$\begin{array}{l}\text { Autumn } \\
\text { (SON) }\end{array}$} & Horizontal transport & -19.8 & -62.6 & 0.7 & -82.7 \\
\hline & $x$ direction & -565.3 & -502.8 & -55.7 & -1104 \\
\hline & $y$ direction & 545.5 & 440.2 & 56.4 & 1061.9 \\
\hline & Stratospheric input & 16.8 & 15.7 & 5.2 & 37.7 \\
\hline & Dry deposition & -53.6 & -101.2 & -53.0 & -207.8 \\
\hline & Net chemistry & 40.8 & 142.8 & 66.7 & 250.3 \\
\hline & Sum & -15.8 & -4.9 & 19.6 & -2.5 \\
\hline
\end{tabular}

and the total of these two terms is $-4.1 \mathrm{Gg}$ day $^{-1}$ in winter months and $-8.7 \mathrm{Gg}$ day $^{-1}$ in summer months. Thus the stratospheric input $\left(18.2 \mathrm{Gg} \mathrm{day}^{-1}\right.$ in winter, and $16.3 \mathrm{Gg} \mathrm{day}^{-1}$ in summer) is important both in winter and in summer, as well as in the other two seasons. Both net chemical production $\left(47.5 \mathrm{Gg} \mathrm{day}^{-1}\right)$ and dry deposition $\left(65 \mathrm{Gg}\right.$ day $\left.^{-1}\right)$ start to increase during spring, but the chemical production does not increase so fast, because meteorological conditions like low temperature and low radiation are less favourable for oxidation during spring over this region. The largest net chemical production in Area1 $\left(72.1 \mathrm{Gg}\right.$ day $\left.^{-1}\right)$ occurs during summertime. This is above 4 times the stratospheric input for this period, but the dry deposition is even higher 
$\left(80.8 \mathrm{Gg}\right.$ day $\left.^{-1}\right)$ during this period. Both chemical production and dry deposition are reduced during autumn, and chemical production is about 2 - 3 times of the stratospheric input. The Tibetan plateau both in summer and winter affects meteorological conditions in Asia. Dynamic processes have a large impact on the distribution of chemical species in this area (Yang et al. 1999; Ma et al. 2002b). Surface ozone levels over this region are strongly influenced by free tropospheric ozone levels.

\subsubsection{Area2}

For Area2, chemical production is always the most important process. The chemical production during winter months is about 8 times the input from the stratosphere, and about 32 times during summer months. Transport from Area2 is large both in winter and spring, and the horizontal loss is mainly compensated for by the ozone imported from the places outside of the south of China. Eastward horizontal transport is $913.4 \mathrm{Gg}$ day $^{-1}$ during spring, and this is smaller than that of the winter months $\left(1181.1 \mathrm{Gg}\right.$ day $\left.^{-1}\right)$ because of strong westerly winds in winter. The spring combines strong westerly winds with increased photochemical activity with the strongest influence from the continent to the West Pacific being found in spring. The transport loss of ozone in summer is large $\left(114.6 \mathrm{Gg} \mathrm{day}^{-1}\right)$, since the summer monsoon brings clean marine air from the ocean in summer. This large export of ozone from Area2 indicates a strong influence over regions east of China. During autumn months Area2 shows a negative ozone tendency $\left(-4.9 \mathrm{Gg}\right.$ day $\left.^{-1}\right)$, because of decreased photochemical production $\left(40.8 \mathrm{Gg}\right.$ day $\left.^{-1}\right)$, still high dry depositions, and efficient horizontal loss $\left(62.6 \mathrm{Gg}_{\text {day }}{ }^{-1}\right)$.

\subsubsection{Area3}

For Area3, dry deposition is large because of forest cover. The largest fraction (about $90 \%$ ) of ozone chemical production is lost by dry deposition in spring months, and about $80 \%$ for other seasons. This shows the effect of vegetation coverage, which is particularly efficient during the growing season. Photochemical production is low in winter $\left(8.64 \mathrm{Gg} \mathrm{day}^{-1}\right)$, while the input from the stratosphere $\left(6.9 \mathrm{Gg} \mathrm{day}^{-1}\right)$ is about the same as chemical production. Photochemical production increases rapidly in spring $\left(37.9 \mathrm{Gg} \mathrm{day}^{-1}\right)$, about 5 times that of stratospheric input, and at the same time dry deposition increases (to $34.0 \mathrm{Gg} \mathrm{day}^{-1}$ ). During summer and autumn months transport to the region to the east is weak and there is almost no net horizontal loss of ozone, because of air from the south where there is strong photochemical production. In Area3, both chemical production and dry deposition do not decrease very much in autumn compared to summer, indicating that biological and photochemical processes are still active in this area.

\subsubsection{Summary}

In summary, for western China (Area1), ozone loss to the surface is always larger than chemical production in this area. Stratospheric input is an important ozone source, compare with processes close to the surface over this region, especially in winter. Dynamic processes are the most important terms of the ozone budget in this region. Area2 is the largest contributor 
of ozone in China, both through dynamic and chemical processes. Chemical production (mainly from anthropogenic emissions) is about 10 times larger than the stratospheric input for Area2. Area3 is different because of its location at a higher latitude and the larger vegetation coverage over this region. We can see here that both the photochemical production and the dry deposition of ozone increase rapidly in spring, which is 4 times larger than it is in winter. In comparison this number is 2 for Area2. Chemical production of ozone is comparable in summer and autumn in this area, indicating the importance of contributions from natural sources in Area3.

Compared with previous ozone budget studies over this region, there are interesting discrepancies. In a study by Ma et al. (2002b), net photochemical ozone production in summertime (1 - 15 July 1995) over China is estimated to be about $-238 \mathrm{Gg} \mathrm{day}^{-1}$. The transport gain is $751 \mathrm{Gg}$ day $^{-1}$, which means that there is large ozone input from regions outside of China. In our study, the averaged net ozone production in summer (JJA) is $432.6 \mathrm{Gg} \mathrm{day}^{-1}$. The transport term acts as a loss process, which is $-119 \mathrm{Gg}$ day $^{-1}$ in summertime. Another study by Mauzerall et al. (2000) gave an annual ozone production in East Asia of $117 \mathrm{Tg} \mathrm{yr}^{-1}\left(320 \mathrm{Gg}^{-1 a y}{ }^{-1}\right)$, and an ozone export to the Pacific Ocean of $58 \mathrm{Tg} \mathrm{yr}^{-1}\left(159 \mathrm{Gg} \mathrm{day}^{-1}\right)$ by using a global CTM model. Therefore, it appears that our model results are in disagreement with Ma et al. (2002b), but close to the results from Mauzerall et al. (2000). It is surprising to see that the discrepancies of the ozone budget from different models can be that large. The most important reason for the disagreements could be the type of model. The regional model has better resolution, which can solve non-linear ozone production in a more reasonable way. However, the regional model has problems with boundary conditions, generally they are predefined and updated with time. The global model suffers from the resolution, which usually is too coarse to resolve the ozone production precisely, especially over the regions with high emissions gradients. The emissions are artificially distributed in the grid, and lead to underestimated ozone peaks over polluted regions with overestimated ozone background levels. Other factors, such as different meteorological data, and the different schemes used in these three models could all be contributing to these differences. Negative ozone production in the regional model, may be caused by very high $\mathrm{NO}_{\mathrm{x}}$ levels. The opposite signs of transport between the regional and the global model can be caused by meteorological data, as well as the boundary conditions.

\section{COLUMN NET OZONE PRODUCTION RATE OVER CHINA}

As shown in Table 3, net ozone chemical production in Area1 is much smaller than in Area2 and Area3. Taking the sizes of the land areas for the three regions into account, we obtained the averaged net column chemical production rate of ozone over each sub-area. The results are shown in the Table 4.

As expected, the minimum value $\left(0.65 \times 10^{11}\right.$ molecules $\left.\mathrm{cm}^{-2} \mathrm{~s}^{-1}\right)$ is found in Area1 in the winter, and the maximum value $\left(11.1 \times 10^{11}\right.$ molecules $\left.\mathrm{cm}^{-2} \mathrm{~s}^{-1}\right)$ is found in Area2 in the summer, this is caused by the distribution of emissions and the variation of radiation. Liu (1988) had given the number of $11.9 \times 10^{11}-22 \times 10^{11}$ (molecules $\mathrm{cm}^{-2} \mathrm{~s}^{-1}$ ) for the ozone column chemical production by total anthropogenic and natural emissions in United States in summer. The averaged number we obtain here is $7.2 \times 10^{11}\left(\right.$ molecules $\left.\mathrm{cm}^{-2} \mathrm{~s}^{-1}\right)$ for China during the summer, this shows that on average ozone production over China is far less than 
1980s levels in the U.S. The ozone production over Area2 is $10 \times 10^{11}$ molecules $\mathrm{cm}^{-2} \mathrm{~s}^{-1}$, which is mainly from anthropogenic emissions. This is about the same level compare with 1980s levels in United States $\left(10 \times 10^{11}\right.$ molecules $\left.\mathrm{cm}^{-2} \mathrm{~s}^{-1}\right)$ caused by anthropogenic emissions. The averaged column net ozone production rate in Area1 is about $20 \%$ and $50 \%$ of the production rates in Area2 and Area3, respectively. The highest value in the summer is $2.8 \times 10^{11}$ (molecules $\mathrm{cm}^{-2} \mathrm{~s}^{-1}$ ), which is smaller than the lowest column production $2.93 \times 10^{11}$ (molecules $\mathrm{cm}^{-2} \mathrm{~s}^{-1}$ ) in winter of Area2. This indicates that chemical processes in Area1 are not the key controller of ozone production in this region. The large net ozone photochemical production in Area2 is due to the large amount of emissions in this region, and lower latitude (some part of this area is in the subtropics). Area3 has averaged column production rates from $1.14 \times 10^{11}$ (molecules $\mathrm{cm}^{-2} \mathrm{~s}^{-1}$ ) in winter to the highest value of $8.77 \times 10^{11}$ (molecules $\mathrm{cm}^{-2} \mathrm{~s}^{-1}$ ) found in autumn, possibly caused by natural emissions in this region.

\section{NET BOUNDARY OZONE PRODUCTION EFFICIENCY IN CHINA}

Because the areas studied are large, most $\mathrm{NO}_{\mathrm{x}}$ is emitted and consumed in the same area. Our budget study showed that only a small percentage (less than $4 \%$ ) of $\mathrm{NO}_{\mathrm{x}}$ is transported out of China. We assumed that all the $\mathrm{NO}_{\mathrm{x}}$ lost leads to $\mathrm{O}_{3}$ production within this area, despite that small fraction of $\mathrm{NO}_{\mathrm{x}}$ loss by transport. And we use net ozone production efficiency rates (En) due to $\mathrm{NO}_{\mathrm{x}}$ emission $\left[\mathrm{En}=\left(\mathrm{O}_{3 \text { Prod }}-\mathrm{O}_{3 \text { Loss }}\right) / \mathrm{NO}_{\mathrm{x} \text { Emis. }}\right]$ defined by Lin et al. (1988). The results of En are shown in Table 5. The averaged concentration ratios of $\mathrm{NMHC} / \mathrm{NO}_{\mathrm{x}}(\mathrm{ppbv} / \mathrm{ppbv}$ ) and mean concentrations over each area are also listed, because both the $\mathrm{NO}_{\mathrm{x}}$ levels and the ratio of $\mathrm{NMHC} / \mathrm{NO}_{\mathrm{x}}$ are important for ozone non-linear production. The values show the sensitivities of net ozone productions in different areas to the $\mathrm{NO}_{\mathrm{x}}$ emission (Loss). Because both $\mathrm{NMHC}$ and $\mathrm{NO}_{\mathrm{x}}$ are emitted close the surface, and the ozone are mainly chemically produced close to the surface, the number we simulated here can be treated as the boundary layer ozone production efficiency.

Previous studies (Isaksen and Rodhe 1978; Liu et al. 1987; Lin et al. 1988) showed that ozone production efficiency is high in rural and remote areas, and ozone production efficiencies decrease with increased $\mathrm{NO}_{\mathrm{x}}$ levels $(0.3$ - $15 \mathrm{ppbv}$ ) (Lin et al. 1988). At the same time, ozone

Table 4. Average column net chemical ozone production rate over China.

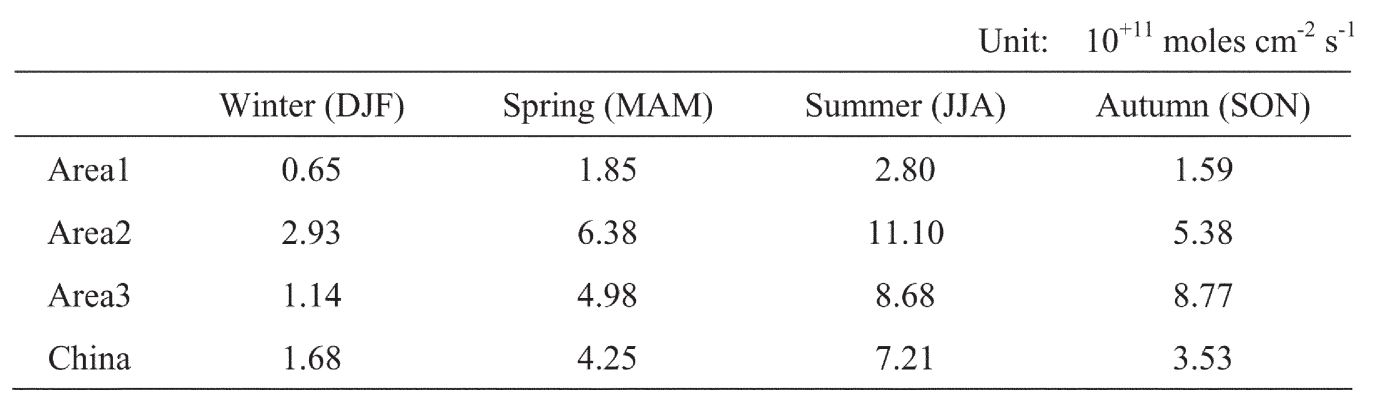


Table 5. Simulated boundary $\mathrm{O}_{3}$ net chemical production efficiency rates (En: Net chemical ozone production efficiency by each $\mathrm{NO}_{\mathrm{x}}$ loss).

\begin{tabular}{llccc}
\hline & & Area1 & Area2 & Area3 \\
\hline Winter & En & 15 & 5 & 5 \\
(DJF) & Ratio of ${\mathrm{NMHC} / \mathrm{NO}_{\mathrm{x}}}$ & 42 & 10 & 10 \\
& Mean $\mathrm{NO}_{\mathrm{x}}$ Concentration & 0.3 & 2.5 & 2.1 \\
\hline Spring & En & 25 & 10 & 12 \\
(MAM) & Ratio of $\mathrm{NMHC} \mathrm{NO}_{\mathrm{x}}$ & 38 & 10 & 12 \\
& Mean $\mathrm{NO}_{\mathrm{x}}$ Concentration & 0.2 & 1.6 & 1.1 \\
\hline Summer & En & 26 & 12 & 12 \\
(JJA) & Ratio of ${\mathrm{NMHC} / \mathrm{NO}_{\mathrm{x}}}$ & 33 & 17 & 15 \\
& Mean $\mathrm{NO}_{\mathrm{x}}$ Concentration & 0.3 & 1.7 & 1.2 \\
\hline Autumn & En & 13 & 5 & 4 \\
(SON) & Ratio of ${\mathrm{NMHC} / \mathrm{NO}_{\mathrm{x}}}$ & 35 & 12 & 11 \\
& Mean $\mathrm{NO}_{\mathrm{x}}$ Concentration & 0.3 & 1.9 & 1.4 \\
\hline
\end{tabular}

production increases with increased ratios of $\mathrm{NMHC} \mathrm{NO}_{\mathrm{x}}$ and the activities of NMHC. A large range of $\mathrm{NMHC} / \mathrm{NO}_{\mathrm{x}}$ ratios from 0.3 to 100 have been studied (Lin et al. 1988), covering rural and urban air conditions. The results indicate that below $10 \mathrm{ppbv}$ of $\mathrm{NO}_{\mathrm{x}}$, ozone production efficiencies increase with an increased ratio of $\mathrm{NMHC} / \mathrm{NO}_{\mathrm{x}}$, because of increased $\mathrm{HO}_{2}+\mathrm{RO}_{2}$ and decreased $\mathrm{OH}$ concentration (Lin et al. 1988). $\mathrm{NO}_{\mathrm{x}}$ and $\mathrm{O}_{3}$ loss in the night-time could significantly suppress ozone production efficiency. Lin et al. (1988) concludes that net ozone production efficiency can be more than $50 \%$ decreased where the $\mathrm{NO}_{\mathrm{x}}$ value is below $1 \mathrm{ppbv}$, when including ozone loss by night-time chemistry.

In our research, as expected, net ozone production efficiency by $\mathrm{NO}_{\mathrm{x}}$ loss is high in spring and summer (summer: 26 for Area1; 12 for Area2; 12 for Area3), and lower in winter and autumn (winter: 15 for Area1; 5 for Area2; 5 for Area3). Because of a quick increase in photochemical activity in spring, values are about twice those of winter. Humidity is an important factor, and the weather in China is highly controlled by the monsoon, with intensive precipitations during spring and summer. Ma et al. (2002b) gave net ozone production differences of about $30 \%$ for decreases in $\mathrm{O}_{3}$ chemical production (refer to their simulation for China and East Asia) by reducing the mixing ratio of water vapour over the model domain. The results show that less water vapour in autumn is an important reason for having low net ozone chemical production efficiencies in autumn compared to spring. Our calculation shows above $50 \%$ difference between spring and autumn. 
The net ozone production efficiency in Area1 is much higher than it is in Area2 and Area3. Due to low $\mathrm{NO}_{\mathrm{x}}$ levels $\left(0.2-0.3 \mathrm{ppbv}\right.$ ) and a high $\mathrm{NMHC} / \mathrm{NO}_{\mathrm{x}}$ ratio (33 to 42), ozone production is very efficient to $\mathrm{NO}_{\mathrm{x}}$ loss. Area1 is obviously under a $\mathrm{NO}_{\mathrm{x}}$ limited regime. For the other two regions, where $\mathrm{NO}_{\mathrm{x}}$ levels are above 1 ppbv during the whole year, ozone production efficiency decreases with increasing $\mathrm{NO}_{\mathrm{x}}$ levels. In the summertime we have a net ozone production efficiency of 12 both for Area2 and Area3, these results agree with other studies (Lin et al. 1988; Olszyna et al. 1994; Jaffe et al. 1996; Carmichael et al. 1998).

\section{CONCLUSIONS}

In this paper, we have presented a model study of tropospheric ozone over China, with a global CTM model. The comparison between model results and measurements shows that the model has the capability to give reasonable ozone distribution and levels close to the surface. In the free troposphere, the model shows good agreements in the middle troposphere, but underestimates the ozone levels above $300 \mathrm{hPa}$, especially for the stations located north of $30^{\circ} \mathrm{N}$. This may be caused by underestimated stratospheric input in the model, but the differences are limited to within 50\% of the observations. At two global baseline sites, the model results are in good agreement with measurements, and this shows that the model is able to capture global features of large-scale circulation. At two continental regional background stations, it is very clear that anthropogenic and biogenic emissions have a strong influence on the measured value. The model gives reasonable levels and variation, but also shows some discrepancies, because of the influence from local emissions. The model simulations for stations near China's coast are generally good in the lower and free troposphere, but underestimate concentration levels close to the surface during the summertime. We have explained some of the differences between observations and model results by regional meteorological conditions and the model's resolution.

The budgets study clearly shows that Central and Eastern China (Area2) is the largest contributor both to primary emissions and ozone generation in China. This area accounts for about $65 \%$ of the net photochemical production, $55 \%$ of the dry deposition, and over $60 \%$ of the net ozone export in China's ozone budgets. The situation is not going to change in this region since the expected energy consumption increase in the future will mostly be located in Area2. Western China (Area1) is characterized by low population density and complex meteorological conditions. Photochemical ozone production plays a less important role compared to stratospheric input and transport therefore dynamic processes are more important in this area. In the northeastern part of China (Area3), both dynamic and photochemical processes are important. Ozone input from the stratosphere is about equal to photochemical production during the winter. And as a result of the larger vegetation cover in this area, dry deposition is particularly important, with about $80 \%$ of the chemical production lost to the surface. China is a net producer of both $\mathrm{O}_{3}$ and $\mathrm{CO}$. On the average, about $70 \%$ of $\mathrm{CO}$ emissions are exported, but only $4 \%$ of the $\mathrm{NO}_{x}$ is exported, and less than $5 \%$ of the NMHC. Based on the budget study, we also studied the ozone production over each region and boundary net chemical ozone production efficiencies by $\mathrm{NO}_{\mathrm{x}}$ loss. The average value of model results over China is 7.2, in agreement with other studies. With the different ratio of $\mathrm{NMHC} \mathrm{NO}_{\mathrm{x}}$ and $\mathrm{NO}_{\mathrm{x}}$ levels, Area1 is an 
area controlled by $\mathrm{NO}_{\mathrm{x}}$ emissions, and ozone produced by photochemical production is small because of the small amounts of $\mathrm{NO}_{\mathrm{x}}$ emissions. Area2 has large ozone production caused by large emissions in this area. Increased $\mathrm{NO}_{\mathrm{x}}$ and $\mathrm{NMHC}$ emissions do not make large differences in ozone production efficiencies over polluted areas, but the dispersion and dilution of emissions will still increase ozone production over rural areas. Area3 shows influences from natural sources, especially NMHC from forests. If $\mathrm{NO}_{\mathrm{x}}$ increased in this area and was transported to remote areas, then ozone production would see a large increase combined with natural NMHC emissions.

\section{REFERENCES}

Anfossi, D., S. Sandroni, and S.Viarengo, 1991: Tropospheric ozone in the nineteenth century: The Moncalieri series. J. Geophys. Res., 96, 17349-17352.

Bachmeier, A. S., R. E. Newell, M. C. Shipham, Y. Zhu, D. R. Blake, and E. V. Browell, 1996: PEM-WEST A: Meteorological overview. J. Geophys. Res., 101, 1655-1678.

Berglen, T. F., T. K. Berntsen, I. S. A. Isaksen, and J. K. Sundet, 2004: A global model of the coupled sulfur/oxidant chemistry in the troposphere: The sulfur cycle.J. Geophys. Res., 109, D19310, doi:10.1029/2003JD003948.

Berntsen, T. K., and I. S. A. Isaksen, 1997: A global 3-D chemical transport model for the troposphere: 1. Model description and CO and Ozone results. J. Geophys. Res., 102, 21239-21280.

Berntsen, T. K., and I. S. A. Isaksen, 1999: Effects of lighting and convection on changes in tropospheric ozone due to $\mathrm{NO}_{\mathrm{x}}$ emissions from aircraft. Tellus $B, \mathbf{5 1}, 766-788$.

Berntsen, T. K., S. Karlsdóttir, and D. A. Jaffe, 1999: Influence of Asian emissions on the composition of air reaching the North Western United States. Geophys. Res. Lett., 26, 2171-2174, doi: 10.1029/1999GL900477.

Brasseur, G. P., R. A. Cox, D. Hauglustaine, I. S. A. Isaksen, J. Lelieveld, D. H. Lister, R. Sausen, U. Schumann, A. Wahner, and P. Wiesen, 1998: European scientific assessment of the atmospheric effect of aircraft emissions. Atmos. Environ., 32, 2329-2418.

Carmichael, G. R., I. Uno, M. J. Phadnis, Y. Zhang, and Y. Sunwoo, 1998: Tropospheric ozone production and transport in the springtime east Asia. J. Geophys. Res., 103, 1064910671.

Chameides, W. L., L. Xingsheng, X. Tang, X. Zhou, L. Chao, and C. S. Kiang, 1998: Is ozone pollution affecting crop yields in China? Geophys. Res. Lett., 26, 867-870.

China Environment Yearbook, China Environment Yearbook, various issues (China Environment Yearbook Press, Beijing, NEPA, 2004. (in Chinese)

China's States statistics yearbook, China's States statistics Bureau, 1997, 2004.

Fahey, D. W., S. G. Donnelly, E. R. Keim, R. S. Gao, R. C. Wamsley, L. A. Del Negro, E. L. Woodbridge, M. H. Proffitt, K. H. Rosenlof, M. K. W. Ko, D. K. Weisenstein, C. J. Scott, C. Nevison, S. Solomon, and K. R. Chan, 1996: In-situ observation of $\mathrm{NO}_{\mathrm{y}}, \mathrm{O}_{3}$, and $\mathrm{NO}_{\mathrm{y}} / \mathrm{O}_{3}$ ratio in the lower stratosphere. Geophys. Res. Lett., 23, 1653-1656. 
Foell, W., M. Amann, G. Carmichael, M. Chadwick, J. P. Hettelingh, L. Hordijk, and D. Zhao, 1995: RAINS-ASIA: An Assessment Model for Air Pollution in Asia, World Bank, Washington DC.

Hesstvedt, E., Ø. Hov, and I. S. A. Isaksen, 1978: Quasi steady-state approximation in air pollution modelling: Comparison of two numerical schemes for oxidant prediction. Int. J. Chem. Kinetics, X, 971-994.

Hough, A. M., 1991: Development of a two-dimentional tropospheric model. Model chemistry. J. Geophys. Res., 96, 7325-7362.

Hudman, R. C., D. J. Jacob, O. R. Cooper, M. J. Evans, C. L. Heald, R. J. Park, F. Fehsenfeld, F. Flocke, J. Holloway, G. Hubler, K. Kita, M. Koike, Y. Kondo, A. Neuman, J. Nowak, and S. Oltmans, 2004: Ozone production in transpacific Asian pollution plumes and implications for ozone air quality in California. J. Geophys. Res., 109, D23S10, doi: 10.1029/2004JD004974.

International Energy outlook, Environmental issues and world energy use, Energy information administration US, 2001.

Isaksen, I. S. A., and H. Rodhe, 1978: A two-dimensional model for the global distribution of gases and aerosol particles in the troposphere, Report AAC-47, Dept. of Meteorology, University of Stockholm.

Isaksen, I. S. A., C. Zerefos, K. Kourtidis, C. Meleti, Stig B. Dalsøren, J. K. Sundet, P. Zanis, and D. Balis, 2005: Tropospheric ozone changes at unpolluted and semi-polluted regions induced by stratospheric ozone changes. J. Geophys. Res., 110, D02302, doi: 10. 1029/2004JD004618.

Jaffe, D., T. Anderson, D. Covert, R. Kotchenruther, B. Trost, J. Danielson, W. Simpson, T. K. Berntsen, S. Karlsdottir, D. Blake, J. Harris, G. Carmichael, and I. Uno, 1999: Transport of Asian air pollution to North America. Geophys. Res. Lett., 26, 711-714, doi: 10. 1029/1999GL900100.

Jaffe, D., H. Price, D. Parrish, A. Goldstein, and J. Harris, 2003: Increasing background ozone during spring on the west coast of North America. Geophys. Res. Lett., 30, 1613, doi: 10.1029/2003GL017024.

Jaffe, D. A., R. E. Honrath, L. Zhang, H. Akimoto, A. Shimizu, H. Mukai, K. Murano, S. Hatakeyama, and J. Merrill, 1996: Measurements of $\mathrm{NO}, \mathrm{NO}_{\mathrm{y}}, \mathrm{CO}$, and $\mathrm{O}_{3}$ and estimation of the ozone production rate at Oki Island, Japan, during PEM-West. J. Geophys. Res., 101, 2037-2048, doi: 10.1029/95JD01699.

Kristin, A., T. K. Berntsen, and H. M. Seip, 2000: Surface ozone in China and its possible impact on agricultural crop yields. Ambio, 29, 294-301.

Lin, X., M. Trainer, and S. C. Liu, 1988: On the nonlinearity of the tropospheric ozone production. J. Geophys. Res., 93, 15879-15888.

Liu, S. C., M. Trainer, F. C. Fehsenfeld, D. D. Parrish, E. J. Williams, D. W. Fahey, G. Hübler, and P. C. Murphy, 1987: Ozone production in the rural troposphere and the implications for regional and global ozone distributions. J. Geophys. Res., 92, 41914207.

Luo, C., J. C. S. John, Z. Xiuji, K. S. Lam, T. Wang, and W. L. Chameides, 2000: A nonurban ozone air pollution episode over eastern China: Observations and model simulations. $J$. Geophys. Res., 105, 1889-1908, doi: 10.1029/1999JD900970. 
Ma, J., H. Liu, and D. Hauglustaine, 2002a: Summertime tropospheric ozone over China simulated with a regional chemical transport model: 1 . Model description and evaluation. J. Geophys. Res., 107, 4660, doi: 10.1029/2001JD001354.

Ma, J., J. Tang, X. Zhou, and X. Zhang, 2002b: Estimates of the chemical budget for ozone at Waliguan observatory. J. Atmos. Chems., 41, 21-48.

Ma, J., X. Zhou, and D. Hauglustaine, 2002c: Summertime tropospheric ozone over China simulated with a regional chemical transport model: 2 . Source contributions and budget. J. Geophys. Res., 107, 4612, doi: 10.1029/2001JD001355.

Ma, J., and J. A. van Aardenne, 2004: Impact of different emission inventories on simulated tropospheric ozone over China: A regional chemical transport model evaluation. Atmos. Chem. Phys., 4, 877-887.

Ma, J. Z., A. Richter, J. P. Burrows, H. Nüß, J. A. van Aardenne, 2006: Comparison of modelsimulated tropospheric $\mathrm{NO}_{2}$ over China with GOME-satellite data. Atmos.Environ., 40, 593-604.

Marenco, A., H. Gouget, P. Nedelec, J. P. Pages, and F. Karcher, 1994: Evidence of a longterm increase in tropospheric ozone from Pic du Midi data series, consequences: Positive radiative forcing. J. Geophys. Res., 99, 16617-16632.

Mauzerall, D. L., D. Narita, H. Akimoto, L. Horowitz, S. Walters, D. A. Hauglustaine, and G. Brasseur, 2000: Seasonal characteristics of tropospheric ozone production and mixing ratios over East Asia: A global three-dimensional chemical transport model analysis. $J$. Geophys. Res., 105, 17895-17910, doi: 10.1029/2000JD900087.

Naja, M., and S. Lal, 1996: Changes in surface ozone amount and its diurnal and seasonal patterns, from 1954 - 55 to 1991 - 93, measured at Ahmedabad (23N), India. Geophys. Res. Lett., 23, 81-84.

Olszyna, K. J., E. M. Bailey, R. Simonaitis, and J. F. Meagher, 1994: $\mathrm{O}_{3}$ and $\mathrm{NO}_{\mathrm{y}}$ relationships at a rural site. J. Geophys. Res., 99, 14557-14564, doi: 10.1029/94JD00739.

Pavelin, E. G., C. E. Johnson, S. Rughooputh, and R. Toumi, 1999: Evaluation of pre-industrial surface ozone measurements made using Schonbein's method. Atmos. Environ., 33, 919-929.

Phadnis, M. J., H. Levy, W. J. Moxim, 2002: On the evolution of pollution from South and Southeast Asia during the winter-spring monsoon. J. Deophys. Res., 107, 4790, 10.1029/ 2002JD002190.

Prather, M., 1986: Numerical advection by conservation of second-order moments. J. Geophys. Res., 91, 6671-6681.

Price, C., J. Penner, and M. Prather, 1997: $\mathrm{NO}_{\mathrm{x}}$ from lightning: 1. Global distribution based on lightning. J. Geophys. Res., 102, 5929-5942.

Richter, A., J. P. Burrows, H. Nüß, C. Granier, and U. Niemeier, 2005: Increase in tropospheric nitrogen dioxide over China observed from space. Nature, 437, 129-132.

Sandroni, S., D. Anfossi, and S. Viarengo, 1992: Surface ozone levels at the end of the nineteenth century in South America. J. Geophys. Res., 97, 2535-2539.

Streets, D. G., and S. T. Waldhoff, 2000: Present and future emissions of air pollutants in China: $\mathrm{SO}_{2}, \mathrm{NO}_{x}$, and CO. Atmos. Environ., 34, 363-374.

Streets, D. G., T. C. Bond, G. R. Carmichael, S. D. Fernandes, Q. Fu, D. He, Z. Klimont, S. 
M. Nelson, N. Y. Tsai, M. Q. Wang, J. H. Woo, and K. F. Yarber, 2003: An inventory of gaseous and primary aerosol emissions in Asia in the year 2000. J. Geophys. Res., 108, 8809, doi: 10.1029/2002JD003093.

Sundet, J. K., 1997: Model studieas with a 3-D Global CTM using ECMWF data, Ph.D. Thesis, Dept. of Geophysics, University of Oslo, Norway, $101 \mathrm{pp}$.

Tang, J., 1995: The observation of surface ozone and preliminary results at Mt. Waliguan of Qinghai province. In: Zhou, X. J. (Ed.), Project: The Ozone Change and Its Influence on Chimate and Environment (I), 19-29. (in Chinese)

Tanimoto, H., Y. Sawa, H. Matsueda, I. Uno, T. Ohara, K. Yamaji, J. Kurokawa, and S. Yonemura, 2005: Significant latitudinal gradient in the surface ozone spring maximum over East Asia. Geophys. Res. Lett., 32, L21805, doi: 10.1029/2005GL023514.

van Aardenne, J. A., G. R. Carmichael, H. Levy, D. Streets, and L. Hordijk, 1999: Anthropogenic $\mathrm{NO}_{\mathrm{x}}$ Emission in Asia in The Period 1990-2020. Atmos. Environ., 33, 633-646.

Wang, C., and F. Guan, 1995: The potential effects and protective strategies of $\mathrm{O}_{3}$ concentration change on Chinese agriculture. Q. J. Appl. Meteorol., 6, 267-273. (in Chinese)

Wang, H. X., L. J. Zhou, and X. Y. Tang, 2006: Ozone concentrations in rural regions of the Yangtze Delta in China. J. Atmos. Chem., 54, 255-265.

Wang, T., A. J. Ding, J. Gao, and W. S. Wu, 2006: strong ozone production in urban plumes from Beijing, China. Geophys. Res. Lett., 33, L21806, doi: 10.1029/2005GL025097.

Wang, T., H. L. A. Wong, J. Tang, A. Ding, W. S. Wu, and X. C. Zhang, 2006: On the origin of surface ozone and reactive nitrogen observed at a remote mountain site in the northeastern Qinghai-Tibetan Plateau, western China. J. Geophys. Res., 111, D08303, doi: 10.1029/2005JD006527.

Wild, O., X. Zhu, and M. J. Prather, 2000: Fast-J: Accurate simulation of in- and blow-cloud photolysis in tropospheric chemical models. J. Atmos. Chem., 37, 245-282.

$\mathrm{Xu}, \mathrm{X}$. B., J. Tang, 1995: Characteristics and reasons of the variations of surface $\mathrm{O}_{3}, \mathrm{NO}_{\mathrm{x}}$, and $\mathrm{SO}_{2}$ at Longfenshan. In: Zhou, X. J. (Ed.), Project: The Ozone Change and Its Influence on Chimate and Environment (I), 67-80. (in Chinese)

Yang, X., M. Wang, and X. Li, 1999: Numerical study of surface ozone in China during summer time. J. Geophys. Res., 104, 30341-30349.

Zhao, C. S., X. X. Tie, G. L. Wang, Y. Qin, and P. C. Yang, 2006: Analysis of air quality in Eastern China and its interaction with other regions of the world. J. Atmos. Chem., 55, 189-204.

Zhou, X. J., 1993: Preliminary analysis of the variations of surface ozone and natric oxides in Lin'an. Acta Meteorol. Sinica, 7, 287-294.

Zhou, X., C. Luo, W. Li, and J. Shi, 1995: The variation of total in China and unusual ozone depletion center over Tibet Plateau. Chinese Sci. Bull., 40, 1396-1398.

Liu, L., J. K. Sundet, Y. Liu, T. K. Berntsen, and I. S. A. Isaksen, 2007: A study of tropospheric ozone over China with a 3-D global CTM model. Terr. Atmos. Ocean. Sci., 18, 515-545, doi: 10.3319/TAO.2007.18.3.515(EA). 